\title{
Modelling landfast sea ice and its influence on ocean-ice interactions in the area of the Totten Glacier, East Antarctica
}

\author{
Guillian Van Achter ${ }^{\text {a,*, Thierry Fichefet }}{ }^{\mathrm{a}}$, Hugues Goosse ${ }^{\mathrm{a}}$, Charles Pelletier ${ }^{\mathrm{a}}$, Jean Sterlin ${ }^{\mathrm{a}}$, \\ Pierre-Vincent Huot ${ }^{\mathrm{a}}$, Jean-François Lemieux ${ }^{\mathrm{b}}$, Alexander D. Fraser ${ }^{\mathrm{c}}$, Konstanze Haubner ${ }^{\mathrm{d}}$, \\ Richard Porter-Smith ${ }^{\mathrm{c}}$ \\ ${ }^{a}$ Earth and Life Institute, Georges Lemaitre Centre for Earth and Climate Research, UCLouvain, Louvain-la-Neuve, Belgium \\ ${ }^{\mathrm{b}}$ Recherche en Prévision Numérique Environnementale/Environnement et Changement Climatique Canada, Québec, Canada \\ c Australian Antarctic Program Partnership, Institute for Marine and Antarctic Studies, University of Tasmania, Hobart, Tasmania 7001, Australia \\ ${ }^{\mathrm{d}}$ Université libre de Bruxelles, Laboratoire de Glaciologie, Brussels, Belgium
}

\section{A R T I C L E I N F O}

\section{Keywords:}

East Antarctica

Sea ice

Ocean

Ice shelves

Landfast sea ice

Totten region

\begin{abstract}
A B S T R A C T
The Totten Glacier in East Antarctica is of major climate interest because of the large fluctuation of its grounding line and of its potential vulnerability to climate change. The ocean above the continental shelf in front of the Totten ice shelf exhibits large extents of landfast sea ice with low interannual variability. Landfast sea ice is either crudely or not at all represented in current climate models. These models are potentially omitting or misrepresenting important effects related to this type of sea ice, such as its influence on coastal polynya locations. Yet, the impact of the landfast sea ice on the ocean-ice shelf interactions is poorly understood. Using a series of high-resolution, regional NEMO-LIM-based experiments, including an explicit treatment of ocean-ice shelf interactions, over the years 2001-2010, we simulate a realistic landfast sea ice extent in the area of Totten Glacier through a combination of a sea ice tensile strength parameterisation and a grounded iceberg representation. We show that the presence of landfast sea ice impacts seriously both the location of coastal polynyas and the ocean mixed layer depth along the coast, in addition to favouring the intrusion of mixed Circumpolar Deep Water into the ice shelf cavities. Depending on the local bathymetry and the landfast sea ice distribution, landfast sea ice affects ice shelf cavities differently. The Totten ice shelf melt rate is increased by $16 \%$ on average and its variance decreased by $38 \%$, while the Moscow University ice shelf melt rate is increased by $+54 \%$ in winter. This highlights the importance of including an accurate landfast sea ice representation in regional and eventually global climate models.
\end{abstract}

\section{Introduction}

Landfast sea ice (fast ice) is stationary sea ice which forms and remains attached to the shore, to an ice front, between shoals or to grounded icebergs (WMO, 1970; Massom et al., 2001; Fraser et al., 2012). Since both polar regions display distinct bathymetric features, there are strong contrasts in fast ice extent and persistence between the Arctic and the Southern Ocean. In the Arctic, thick sea ice can be grounded in shallow waters, with the seaward fast ice edge often located along the 20-30 m isobath (Mahoney et al., 2007; Lieser, 2004). In the Antarctic, dynamically-formed fast ice occurs when sea ice imported by winds is blocked by restrictive geometry, especially icebergs which are often grounded in 400-500 m deep water (Wadhams et al., 1987; König Beatty and Holland, 2010; Massom et al., 2001). Such mechanical anchors lead to much larger fast ice extent in the Southern Ocean. Thermodynamically-formed fast ice takes place in quiescent periods between groups of grounded icebergs (Giles et al., 2008; Fraser et al., 2012). In both hemispheres, once the ice is blocked, two mechanisms are generally thought to accelerate the growth of fast ice. In shallow waters, fast local freezing of water happens due to the lack of deeper warmer water acting as a source of heat through convection (König Beatty and Holland, 2010). Then, pack ice imported by onshore winds integrates and consolidates the fast ice pack (Wadhams et al., 1987).

Fast ice plays an important role in the ocean-ice-atmosphere system. As it is at rest and includes few leads, it decreases the transfer of heat, moisture and momentum between the atmosphere and the underlying ocean (Johnson et al., 2012; Itkin et al., 2015). In the Southern Ocean, the position of fast ice and polynyas are strongly linked. Because westward sea ice advection, due to easterly wind and westward coastal current, is blocked by fast ice, polynyas are frequently formed on the western side of fast ice (Massom et al., 1998; Tamura

\footnotetext{
* Corresponding author.

E-mail address: guillian.vanachter@uclouvain.be (G. Van Achter).
} 
et al., 2008; Nihashi and Ohshima, 2015; Fraser et al., 2019). Fast ice also forms an important interface between the Antarctic ice sheet and the ocean. It mechanically stabilises ice shelves, delaying their calving and ultimately affecting ice sheet mass balance (Massom and Stammerjohn, 2010; Massom et al., 2018).

Despite the physical significance of fast ice for atmosphere-iceocean interactions, most sea ice models are either unable to simulate it or they represent it quite crudely (Lemieux et al., 2015). For the Arctic, a number of studies have addressed the mechanisms that form and maintain fast ice. Lemieux et al. $(2015,2016)$ developed two parameterisations to simulate fast ice: (1) a basal stress parameterisation, which represents the effect of grounded ice keels, and (2) a tensile strength parameterisation, which can render the ice arching mechanism. Other studies rely on prescribing fast ice through the use of a mask to set the ice velocity to zero (Johnson et al., 2012; Rozman et al., 2011), or have prescribed fast ice with some criteria, such as sea ice thickness over a certain water depth (Lieser, 2004), or sea ice velocity over a certain water depth (Wang et al., 2014). In the Antarctic, fast ice mechanisms are less well understood. Giles et al. (2008) identified dynamic and thermodynamic fast ice, whereas Nakayama et al. (2014) showed the importance of grounded icebergs in the formation of fast ice. No parameterisation has been tested yet to simulate fast ice in this region. Some regional ocean-sea ice models, as in Gwyther et al. (2014), prescribe sea ice from observations to lead the model into including fast ice. Other regional models use prescribed fast ice, either by imposing a constant sea ice thickness over a certain region, or by setting its velocity at zero to render the blocking of sea ice advection by subgrid-scale grounded icebergs (Kusahara et al., 2016; St-Laurent et al., 2017).

Our focus in this study is on the fast ice in the Totten Glacier area, located on the Sabrina Coast in East Antarctica (108-129 $9^{\circ}$ East). The Sabrina Coast is a key area to test the importance of fast ice as it harbours marine terminating glaciers, ice shelves, large tracts of fast ice and strong sea ice formation. The Totten ice shelf (TIS) drains over $570000 \mathrm{~km}^{2}$ of the Aurora basin, East Antarctica (Rignot et al., 2008; Young et al., 2011). Significant grounding-line fluctuation driven by changes in the ocean has been observed throughout the past (Aitken et al., 2016) making the region potentially vulnerable to rapid ice sheet collapse (Roberts et al., 2011). The calving rate at the TIS features significant seasonality (Greene et al., 2018), partly due to loss of buttressing from the breakup of seasonal fast ice. There has been some indication of ice shelf thinning during the last decade (Khazendar et al., 2013), although it remains unclear whether this represents a long-term trend (Paolo et al., 2015; Gwyther et al., 2018). Moreover, modified Circumpolar Deep Water (mCDW) on-shelf intrusions towards the TIS have been linked to the strength of the Antarctic Slope Current (ASC) (Nakayama et al., 2021). Understanding how changes in the ocean circulation and properties are interfering with the basal melt of the Antarctic ice shelves is crucial for predicting future sea level rise.

The first objective of this study is to evaluate under which conditions realistic fast ice representations can be simulated in our area of interest. In other words, we focus on the mechanisms that are forming and maintaining fast ice in the Totten region and how to include them in a model. The second objective of this paper is to evaluate the impact of fast ice on the system, more precisely, on the ocean and ice shelves. In order to answer these questions, we designed four simulations with a high-resolution, regional configuration of the NEMO3.6-LIM3 model, to evaluate the contributions of the sea ice tensile strength parameterisation (Lemieux et al., 2016) and the icebergs acting as barrier for sea ice advection to fast ice formation.

This manuscript is organised as follows. The model, regional configuration and experimental design are described in Section 2. In Section 3 , the model is evaluated. In Section 4 , we analyse the fast ice simulated in the different experiments. Then we investigate the sensitivity of sea ice, ocean and ice shelves to fast ice in Section 5 . Conclusions are finally given in Section 6.

\section{Material and methods}

\subsection{Ocean-sea ice model}

We make use of NEMO 3.6 (Nucleus for European Modelling of the Ocean) (Madec, 2008) that includes the ocean model OPA (ocean parallelise), coupled with the sea ice model LIM3 (Louvain-la-Neuve sea ice model) (Vancoppenolle et al., 2009; Rousset et al., 2015), hereafter referred to as NEMO-LIM. NEMO is a state-of-the-art, finite-difference ocean model based on primitive equations. Our setting includes a polynomial approximation of the reference thermodynamic equation of seawater (TEOS-10) (IOC, SCOR, IAPSO, 2010) optimised for a Boussinesq fluid (Roquet et al., 2014). Vertical turbulent mixing is rendered through a Turbulent Kinetic Energy (TKE) scheme (Bougeault and Lacarrere, 1989; Gaspar et al., 1990; Madec et al., 1998). The enhanced vertical mixing coefficient used in this scheme is fixed to 20. A subgrid-scale distribution of sea ice thickness is used with 5 categories (Bitz et al., 2001). The drag coefficient is set to $7.1 \times 10^{-3}$ at the sea ice-ocean interface and $2 \times 10^{-3}$ at the sea ice-atmosphere one (Massonnet et al., 2014). Ice shelf cavities with explicit ocean-ice shelf interactions are represented by the ice shelf module introduced in NEMO by Mathiot et al. (2017), using the three-equations formulation from Jenkins (1991). Transfer coefficients for heat $\left(\gamma_{T}\right)$ and salt $\left(\gamma_{S}\right)$ between the ocean and ice shelves are velocity dependent (Dansereau et al., 2014): $\gamma_{T, S}=\Gamma_{T, S} \times u_{*}$. The friction velocity is given by $u_{*}=$ $C_{d} \times \sqrt{u_{T M L}^{2}}$ and constant values of $\Gamma_{T}$ and $\Gamma_{S}$ taken from Jourdain et al. (2017) are used $\left(\Gamma_{T}=2.21 \times 10^{-2}\right.$ and $\Gamma_{S}=6.19 \times 10^{-4}$ for temperature and salinity, respectively), $C_{d}$ is the top drag coefficient, set to $8 \times 10^{-3}$, and $u_{T M L}$ is the ocean velocity in the top mixed layer, which is either the top $30 \mathrm{~m}$ of the water column or the top model layer (if thicker than $30 \mathrm{~m}$ ) (Losch, 2008).

\subsection{The Totten24 model configuration}

Here, we use a regional configuration of NEMO-LIM, referred to as Totten24. The horizontal grid is a $1 / 24^{\circ}$ refinement (less than $2 \mathrm{~km}$ grid spacing) of the ORCA family (Madec et al., 1998), centered on the continental shelf in front of the TIS, East Antarctica, and covering an area between $108-129^{\circ} \mathrm{E}$ and $63-68^{\circ} \mathrm{S}$ (Fig. 1). The NEMO and LIM time steps are $150 \mathrm{~s}$ and $900 \mathrm{~s}$, respectively. The vertical discretisation has 75 levels with level thickness increasing with depth and partial cells used for better representing bedrock and ice shelf base (Adcroft et al., 1997). The ocean layer directly underneath the ice shelf base varies between $30 \mathrm{~m}$ near the cavity front and $80 \mathrm{~m}$ in the center of the cavity. The bathymetry and ice shelf draft datasets are part of the NASA Making Earth System Data Records for Use in Research Environments (MEaSUREs) program, which contains a bathymetry map of Antarctica based on mass conservation, streamline diffusion, and other methods (Morlighem et al., 2020).

The ocean boundary conditions and initial conditions are derived from a 1979-2014 simulation with an eORCA025 (1/4 ${ }^{\circ}, 75$ levels) periAntarctic NEMO-LIM configuration (Pelletier et al., 2021) (hereafter referred to as PARASO). At the west, north and east boundaries, the model is forced daily with sea surface elevation (SSH), temperature, salinity, ocean velocities, sea ice concentration, sea ice thickness and snow thickness over sea ice. Surface boundary fluxes are computed using the CORE bulk formula (Large and Yeager, 2004), with atmosphere input coming from the fifth generation ECMWF atmospheric reanalysis (ERA5, Hersbach et al., 2020). No surface salinity restoring is applied. At the lateral boundaries, a flow relaxation scheme (Engedahl, 1995) is applied to the three-dimensional ocean variables and twodimensional sea ice variables. A Flather scheme (Flather, 1994) is used for barotropic velocities and sea surface elevation. Furthermore, the SSH and barotropic velocities from the FES2014 tide model (Carrère et al., 2012) are added to the boundary for the tide components K1, K2, M2, P1, O1, S2, 2N2, Mm, M4, Mf, Mtm, MU2, N2, NU2, Q1, S1, L2, T2, as in Maraldi et al. (2013), Jourdain et al. (2019), Huot et al. (2021). 


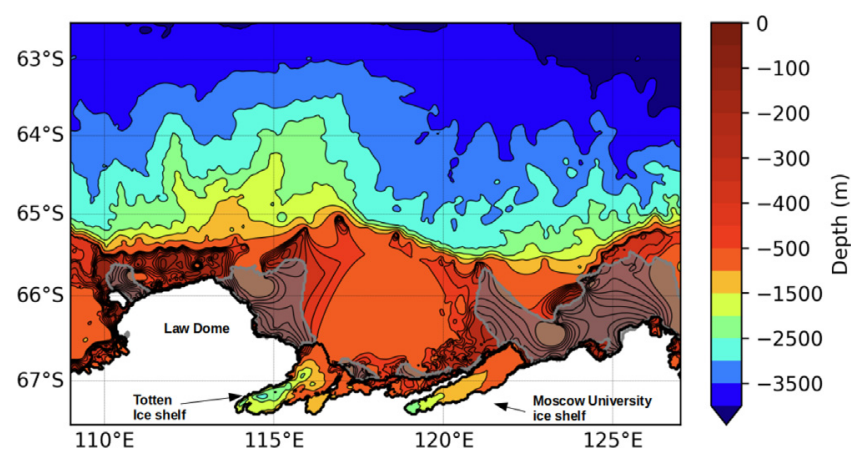

Fig. 1. Model bathymetry and domain. The contour interval is $50 \mathrm{~m}$ up to $500 \mathrm{~m}$ depth and $500 \mathrm{~m}$ up to $4500 \mathrm{~m}$ depth. Ice shelf cavities are surrounded by a thick black line. The 0.75 landfast sea ice observed frequency from Fraser et al. (2020) is shown by the shaded grey areas.

\subsection{Experimental design}

To incorporate the icebergs in our regional configuration, we use an iceberg dataset which is extracted from the remote sensed mosaic 'RAMP AMM-1 SAR Image Mosaic of Antarctica, Version 2' (Jezek et al., 2013). It covers the September-October months of 1997. The dataset does not specify whether icebergs are grounded or not. We created an iceberg mask by imposing a model cell as a grounded iceberg (bathymetry value is set to zero) when the cumulative area of all icebergs within a cell reached $2 \mathrm{~km}^{2}$. Then, to avoid creating iceberg walls and to keep a regular oceanic circulation, we filtered the mask to avoid prescribing neighbouring iceberg grid cells. Finally, we only kept the icebergs located in oceanic areas shallower than $450 \mathrm{~m}$.

As a fast ice parameterisation, we use the sea ice tensile strength parameterisation developed by Lemieux et al. (2016) to reproduce ice arching mechanism in a sea ice model. As the ocean is quite deep in the region of interest, we do not use the basal stress parameterisation associated with the grounding of sea ice ridges; anchor points are only provided by grounded icebergs. The momentum equation is solved with the elastic-viscous-plastic (EVP) approach (Hunke, 2001). The stresses are calculated from:

$\frac{\partial \sigma_{1}}{\partial t}+\frac{\sigma_{1}}{2 T_{d}}+\frac{p}{2 T_{d}}=\frac{\zeta}{T_{d}} D_{D}$

$\frac{\partial \sigma_{2}}{\partial t}+\frac{e^{2} \sigma_{2}}{2 T_{d}}=\frac{\zeta}{T_{d}} D_{T}$

$\frac{\partial \sigma_{12}}{\partial t}+\frac{e^{2} \sigma_{12}}{2 T_{d}}=\frac{\zeta}{2 T_{d}} D_{s}$

where $\sigma$ is the internal ice stress tensor with components $\sigma_{11}=\sigma_{x x}$, $\sigma_{22}=\sigma_{y y}, \sigma_{12}=\sigma_{x y}, \sigma_{1}=\sigma_{11}+\sigma_{22}, \sigma_{2}=\sigma_{11}-\sigma_{22}, D_{D}=\frac{\partial u}{\partial x}+\frac{\partial v}{\partial y}$, $D_{T}=\frac{\partial u}{\partial x}-\frac{\partial v}{\partial y}, D_{S}=\frac{\partial u}{\partial y}+\frac{\partial v}{\partial x}, u$ and $v$ are the horizontal components of the sea ice velocity vector, $p$ is a pressure-like term, $T_{d}$ is the damping time scale for elastic waves, $\zeta$ is the bulk viscous coefficient, and $e$ is the eccentricity of the elliptical yield curve. Based on König Beatty and Holland (2010), an isotropic tensile strength is introduced in Eqs. (1) by setting:

$\zeta=P_{p}\left(1+k_{t}\right) / 2 \Delta^{*}$

$p=\left(1-k_{t}\right) P$

where $P_{p}$ is the compressive ice strength parameterised following Lipscomb et al. (2007), $\Delta^{*}=\max \left(\Delta, \Delta_{\min }\right), \Delta=\left\{\left[D_{D}^{2}+e^{-2}\left(D_{T}^{2}+D_{S}^{2}\right)\right]^{\frac{1}{2}}\right\}$, $\Delta_{\min }$ is a small deformation to prevent a singularity on $\zeta$ when $\Delta \rightarrow 0$, $k_{t}$ is a parameter that characterises the amount of tensile strength ( $T$ ) as a function of the ice strength in compression $\left(T=k_{t} P_{p}\right)$ and $P=P_{p} \Delta / \Delta^{*}$. The principal stresses, which correspond to the maximum
Table 1

Names and descriptions of the simulations carried out in the study.

\begin{tabular}{lll}
\hline & Tensile strength & Grounded icebergs \\
\hline REF & Yes & Yes \\
ICB & No & Yes \\
TENS & Yes & No \\
noALL & No & No \\
\hline
\end{tabular}

and minimum normal stresses, are given by:

$\sigma_{p 1}, \sigma_{p 2}=\frac{\sigma_{11}+\sigma_{22}}{2} \pm \sqrt{\left(\frac{\sigma_{11}-\sigma_{22}}{2}\right)^{2}+\sigma_{12}^{2}}$

Still following Lemieux et al. (2016), larger uniaxial tensile stresses can be sustained by the ice by decreasing the value of $e$. Furthermore, only $k_{t}>0$ allows both $\sigma_{p 1}$ and $\sigma_{p 2}$ to be positive, so that the ice has isotropic tensile strength. Based on an initial optimisation procedure, $e$ and $k_{t}$ are set here equal to 1.2 and 0.2 , respectively. We use 720 subcycling iterations of the EVP scheme to solve the momentum and the stress equations.

Our experimental design consists of one reference simulation and a set of three sensitivity experiments. For all four simulations, a 2year spin-up is performed with forcings coming from the 1999-2000 period. Then, each simulation is run from 2001 to 2010. All simulations include both the tide constituents and the ocean-ice shelf interactions (i.e., open ice shelf cavities and interactive basal melt computations). The reference simulation (REF) includes both the sea ice tensile strength parameterisation and the prescribed grounded icebergs. As shown in Table 1, the sensitivity experiments include only the grounded icebergs (ICB), only the sea ice tensile strength parameterisation (TENS), or neither of those (noALL).

\section{Evaluation of the reference simulation}

In this section, we assess the performance of the REF simulation in comparison with available observations. First, we evaluate the overall sea ice cover (including both pack ice and fast ice) against the NOAA/NSIDC Climate Data Record of Passive Microwave Sea Ice concentration, Version 3 dataset (Meier et al., 2017). We focus on the mean sea ice extent in both summer and winter season and also on its seasonal cycle. The simulated sea ice extent appears somewhat overestimated in winter and underestimated in summer (Fig. 2a, b, c, d), which is a typical bias of NEMO-LIM (e.g., Rousset et al., 2015; Barthélemy et al., 2018). In summer, the sea ice extent is well estimated only in areas of fast ice. The simulated seasonal cycle lays mostly within the observed interannual variability of sea ice extent (Fig. 2e).

The fast ice modelled distribution is shown in Fig. 3. The simulated fast ice frequency, defined as the percentage of days in a year with a 2week mean sea ice velocity lower than $0.005 \mathrm{~m} / \mathrm{s}$, compares relatively well with the observed fast ice frequency (Fraser et al., 2020). Most of the multiyear fast ice (frequency above 0.9) simulated in REF matches the observations, except for a pack on the eastern side of Law Dome (LD pack - between $116^{\circ}$ and $118^{\circ} \mathrm{E}$ ). Two areas of observed fast ice are underestimated in extent in REF: one on the western side of the LD pack, where almost no fast ice is simulated, and another one on the Eastern side of $125^{\circ} \mathrm{E}$, where the simulated fast ice is scarcer than in the observations (simulated frequency of 0.2 compared to more than the 0.9 observed one). Following Giles et al. (2008)'s categorisation of fast ice in the Totten area (Fig. 10 in Giles et al., 2008), it appears that the correctly simulated fast ice is mostly multiyear dynamically-formed fast ice and that most of the underrepresented fast ice is yearly thermodynamically-formed fast ice. The lack of simulated fast ice, in some areas, might be due to a misrepresentation of the thermodynamically-formed fast ice in our model for some areas, or, since thermodynamically-formed fast ice occurs in quiescent periods between groups of grounded icebergs (Giles et al., 2008; Fraser et al., 
(a) REF in summer

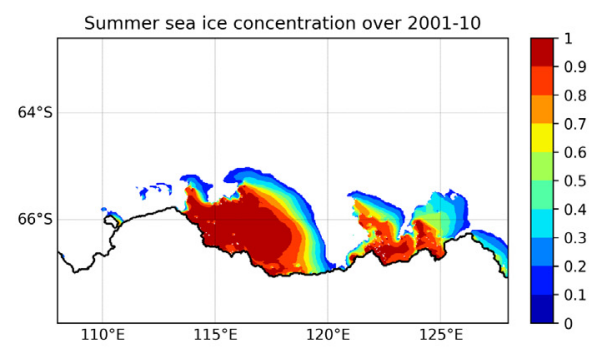

(c) REF in winter

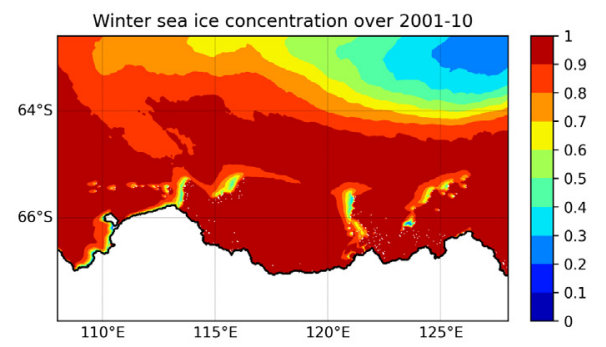

(b) Observation in summer

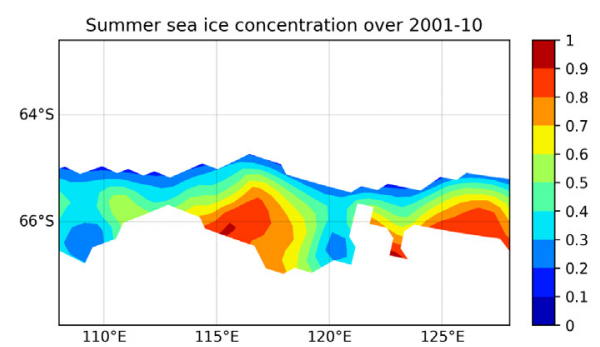

(d) Observation in winter

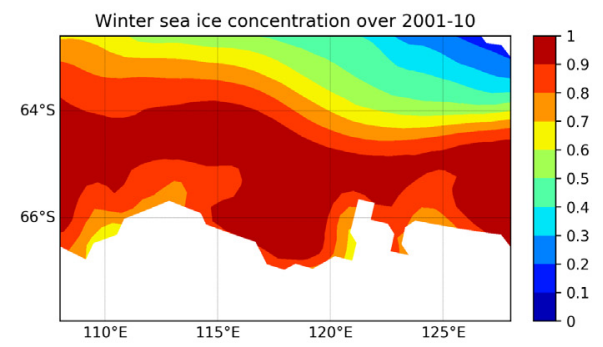

(e)

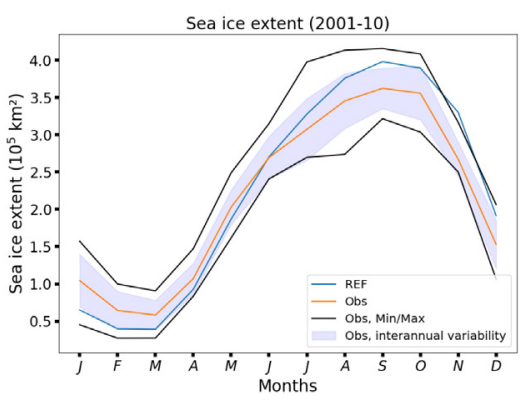

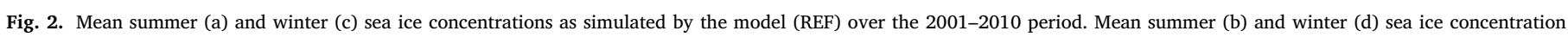

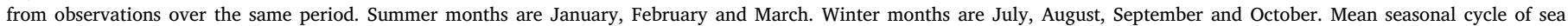

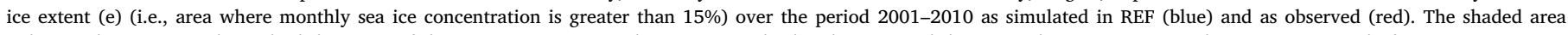

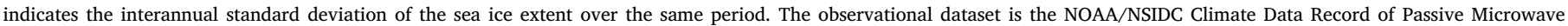
Sea Ice concentration (Meier et al., 2017).

2012), to an inaccurate iceberg representation. Indeed, in our simulation, the grounded icebergs position is static throughout the 10 year run, while in reality icebergs may drift and induce changes in the fast ice spatial distribution.

Fig. 3c,d suggests that the simulated sea ice production related to the fast ice position is in good agreement with observations (Tamura et al., 2008, 2016). Indeed, all the observed areas of high sea ice production are depicted in $\mathrm{REF}$, with sea ice production reaching more than $8 \mathrm{~m} / \mathrm{yr}$ in the five main production zones, as it is observed. Small dissimilarities in spatial distribution exist, e.g. in the Dalton Polynya, where areas of simulated sea ice production exceeding $5 \mathrm{~m} / \mathrm{yr}$ are narrower compared to observations. Nevertheless, the too small sea ice production area are compensated by their higher values of sea ice production, as the difference between simulated and observed sea ice production over all the continental shelf is smaller than $10 \%$. The spatial disagreements may be related to the differences between simulated and observed fast ice, or the spatial sampling which has much higher resolution in our simulations compared to observations. The simulated polynya locations for the May-September months (which is defined as an area with ice thickness lesser than $0.2 \mathrm{~m}$ and ice concentration lesser than 15\%) reproduces well the main features of the observational dataset (Fig. 3e,f), except for the two polynyas near Law Dome, whose size and frequency are slightly overestimated compared to observations (Kern, 2012), and for the two polynyas near the eastern side of the domain, which are not represented in REF.

The mean simulated sea ice thickness for the May-October months (Fig. 4a) is overestimated by 30 to $50 \%$ in the fast ice area compared to the LEGOS observational product (Guerreiro et al., 2017). However, it is worth mentioning that these observations have large uncertainties, as microwave altimeter measurements of sea ice thickness are very difficult in iceberg-infested regions (Fig. 4c). While the observed sea ice thickness is lower than the simulated one, very thick fast ice is to be expected (Ushio, 2006), especially in dynamically-formed fast ice areas. Since the sea ice thermodynamical growth reduces as thickness increases, if the model overestimates the ice thickness, this should not impact our results. Indeed, the overestimation is circumscribed to the fast ice and thus bears limited consequences on sea ice dynamics.

The simulated ocean properties are compared against CTD measurements from Rintoul et al. (2016) and the Marine Mammals Exploring the Oceans Pole to Pole (MEOP) ocean observational product (Treasure et al., 2017). The simulated temperatures are in good agreement with Rintoul et al. (2016)'s observations, with less than $0.1{ }^{\circ} \mathrm{C}$ of difference, except between $450-550 \mathrm{~m}$, where the modelled ocean presents a warm bias of $+0.5{ }^{\circ} \mathrm{C}$ (Fig. 5a). Regarding the simulated salinities (Fig. 5b), they show a fresh bias of $-0.2 \mathrm{~g} / \mathrm{kg}$. This discrepancy is at least partly due to the ocean model outputs (PARASO) 
(a) REF - Landfast sea ice

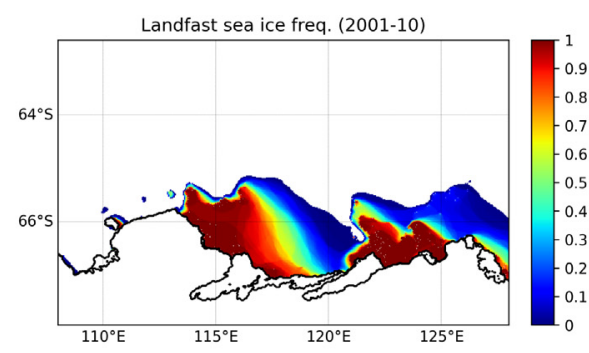

(c) REF - Sea ice production

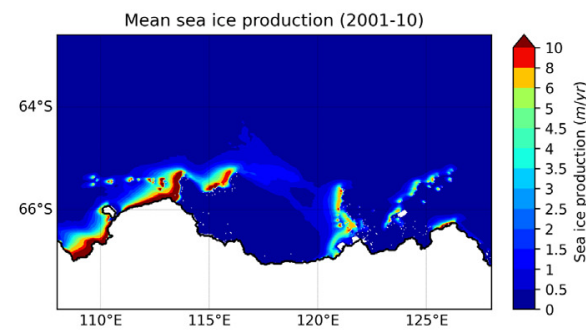

(e) REF - Polynya location

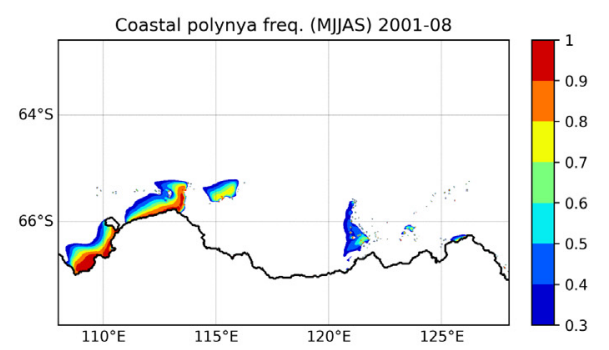

(b) Observation - Landfast sea ice

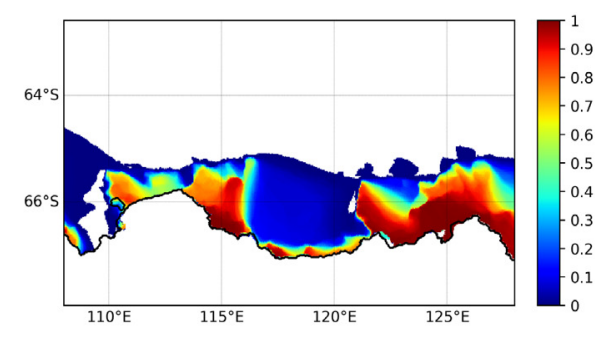

(d) Observation - Sea ice production

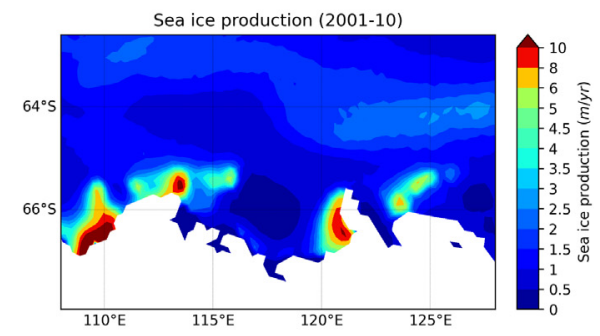

(f) Observation - Polynya location

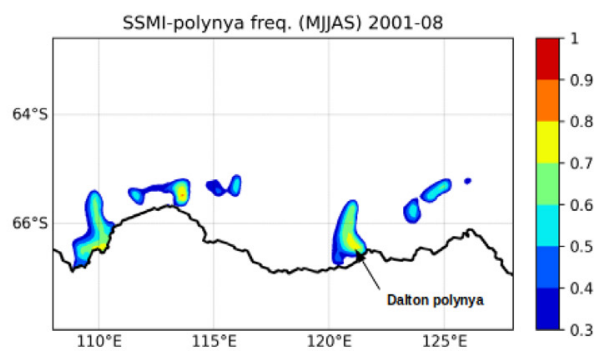

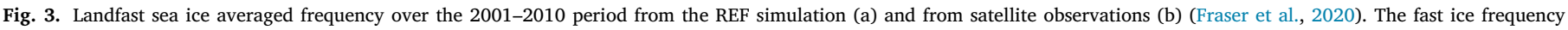

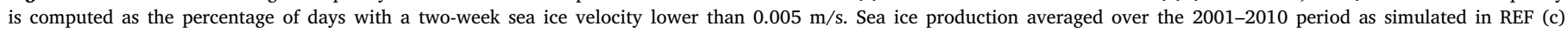

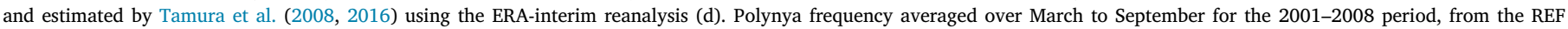
simulation (e) and from satellite observations (f) (Kern, 2012).

used as lateral boundary conditions, which exhibits lower salinities than observed (Fig. 5c). The salinity bias is constant throughout the water column, implying a similar vertical density stratification between REF and Rintoul et al. (2016)'s observations. Since the typical biases of our simulated water masses are comparable to the biases of other modelling studies on the Antarctic continental shelf (Jourdain et al., 2017; Huot et al., 2021), we consider our simulations suitable for this ocean-ice interaction study but these biases must be kept in mind in the interpretation of our results.

The different simulated water masses are shown in Fig. 5c. The $\mathrm{mCDW}$ is clearly identified for the 3 products, consisting of relatively warm and saline water (mCDW definition is $T>0{ }^{\circ} \mathrm{C}$ and $S>34.5$ $\mathrm{g} / \mathrm{kg}$, in this study $T \sim-0.4{ }^{\circ} \mathrm{C}$ is used to identify mCDW over the continental shelf). The observed mCDW can reach much higher salinity than in our simulation. Water masses with salinity between 34 and 34.4 $\mathrm{g} / \mathrm{kg}$, i.e. the Winter Water (WW), produced by winter time convection beneath sea ice, and the Ice Shelf Water (ISW), resulting by mixing between glacial meltwater (colder than $-1.92{ }^{\circ} \mathrm{C}$ ) and ambient shelf water, are both well simulated in comparison with MEOP observations. The warm Antarctic Surface Water (AASW, $-1{ }^{\circ} \mathrm{C}<T<+3{ }^{\circ} \mathrm{C}$ ), produced by summer heating that overlies the WW, is also relatively well reproduced. Finally, the Dense Shelf Water (DSW), transformed by local processes such as atmosphere cooling and brine rejection associated with sea ice formation (surface freezing temperature and $S>34.5 \mathrm{~g} / \mathrm{kg}$ ), is underrepresented in our simulation, with lower salinity, despite realistic simulated sea ice production. This agrees with the results of Silvano et al. (2017), which did not find any DSW in the Totten and Moscow University continental shelf.

The spatial distribution of the simulated ocean temperature is displayed in Fig. 6. At 200 and $300 \mathrm{~m}$ depths, $\mathrm{WW}$ is found on the continental shelf. Deeper, mCDW is present near the shelf break, converging towards both the Totten and Moscow University ice shelf front. The mCDW temperature reaches up to $-0.4{ }^{\circ} \mathrm{C}$ in front of TIS cavity and up to $0.4{ }^{\circ} \mathrm{C}$ at the shelf break, in good agreement with both Rintoul et al. (2016) and Nitsche et al. (2017), who found warm mCDW with the same temperature at the same locations.

Finally, Fig. 7 assesses the simulated area averaged basal melt rate for both Totten and Moscow University ice shelves compared to the observation-based estimates of Rignot et al. (2013). The mean simulated melt rate of $3.98 \mathrm{~m} / \mathrm{yr}$ of the Moscow University ice shelf (MUIS) compares well with the $4.7 \pm 0.8 \mathrm{~m} / \mathrm{yr}$ observation-based estimate. On the other hand, the TIS experiences in the model a steady melt rate of $6.05 \mathrm{~m} / \mathrm{yr}$, which is largely underestimated compared to the observation-based estimate of $10.47 \pm 0.7 \mathrm{~m} / \mathrm{yr}$. As shown in other studies (Jourdain et al., 2017; Gwyther et al., 2014), it is really a challenge to simulate accurately the melt rates in all cavities. Moreover, this underestimation may partly be attributed to the lack of observations of the TIS cavity bathymetry, which may play a dominant role in warm water intrusion (Rintoul et al., 2016; Silvano et al., 2019).

Unlike TIS, the MUIS melt rate shows a strong seasonal cycle, with maximum values around January-February and minimum values around May-June (Fig. 7b). The higher seasonal variability of the 


\section{(a) REF - Sea ice thickness}

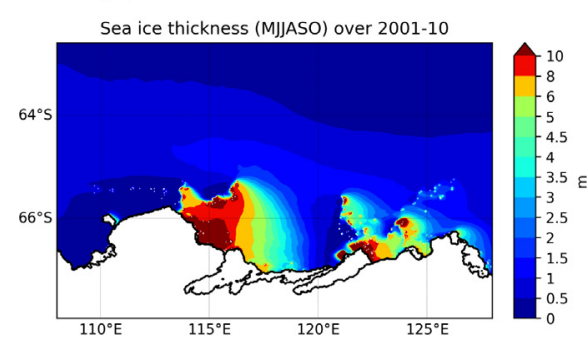

(b) Observation LEGOS

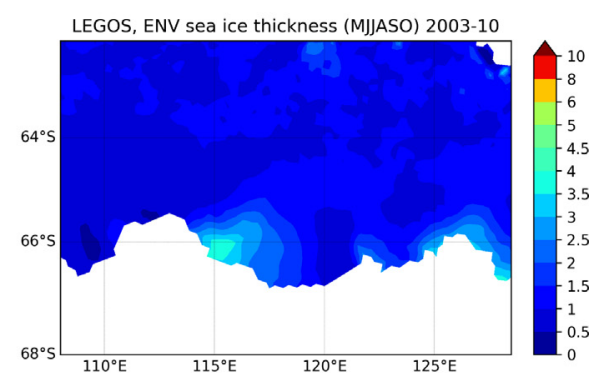

(c) Observation uncertainty LEGOS

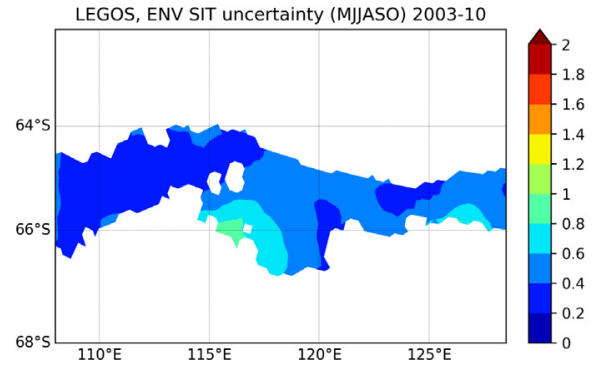

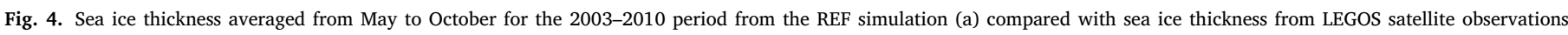
(b) averaged over the same period, with the observation uncertainty (c) (Guerreiro et al., 2017).

(a)

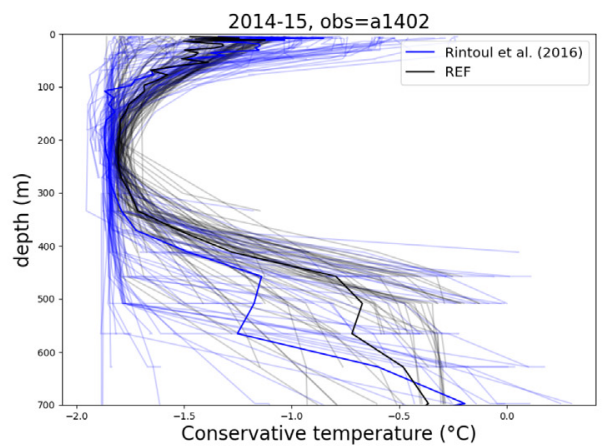

(c)

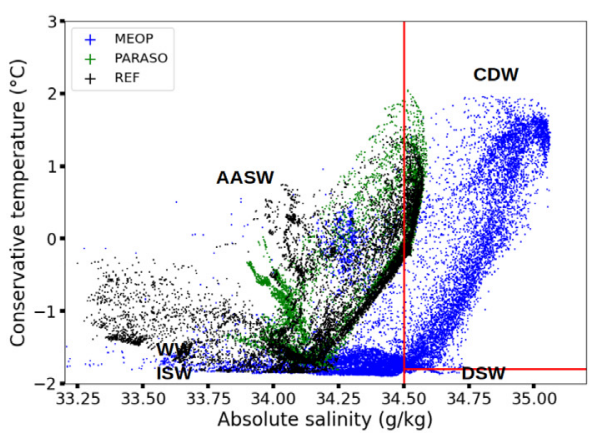

(b)

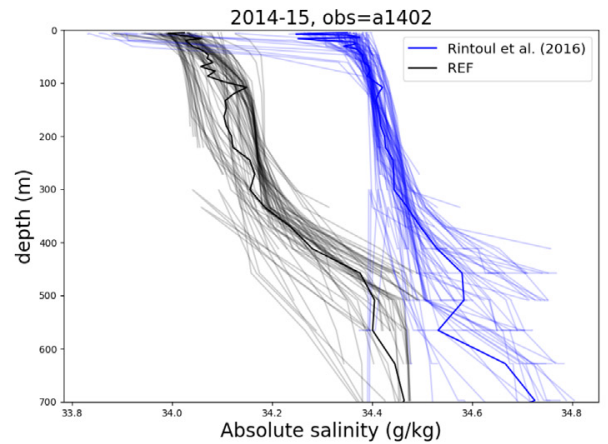

(d)

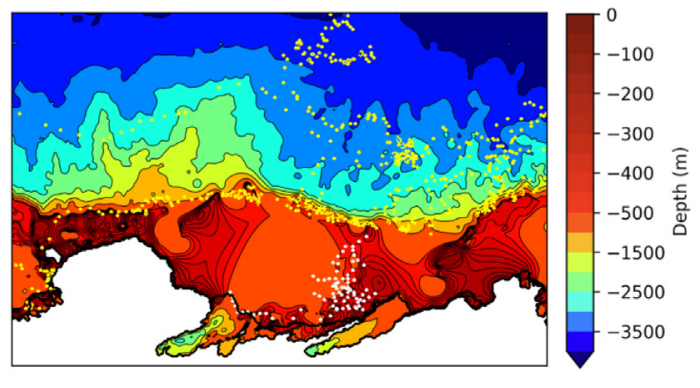

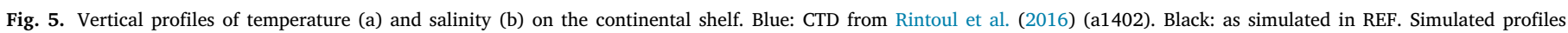

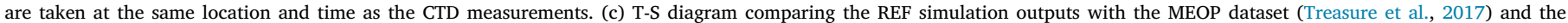

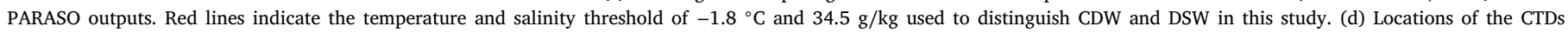
used in panels a, b and c: white dots are CTDs from Rintoul et al. (2016) and yellow dots are from MEOP. The contour lines are bathymetry levels.

MUIS melt rate could be explained by the seasonal variations of the Antarctic Slope Current (ASC) intensity. The ASC features a stronger zonal component during summer at depth (zonal arrows along the Antarctic Slope Front (ASF), see the black boxes in Fig. 8a, b), which both limits across-slope exchanges and brings cold water masses in front of the MUIS cavity. These two processes combine together to decrease the temperature of the ocean masses entering the MUIS cavity (the average temperature of the water masses entering the cavity is 
(a)

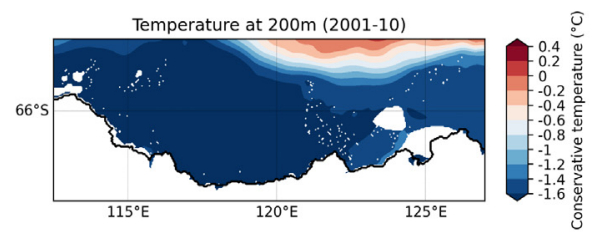

(c)

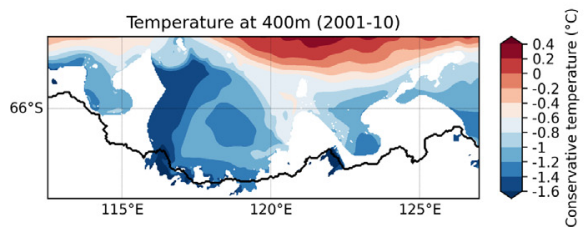

(b)

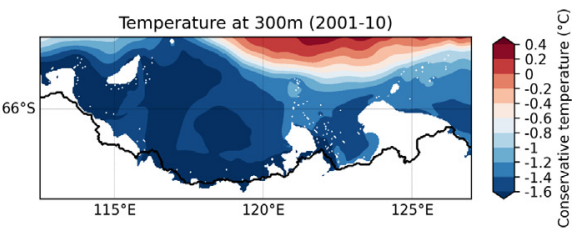

(d)

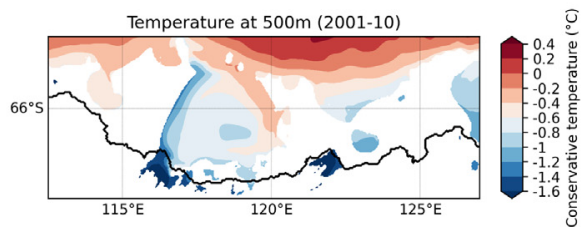

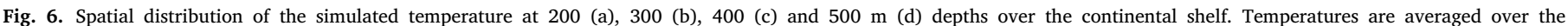
2001-2010 period.

(a)

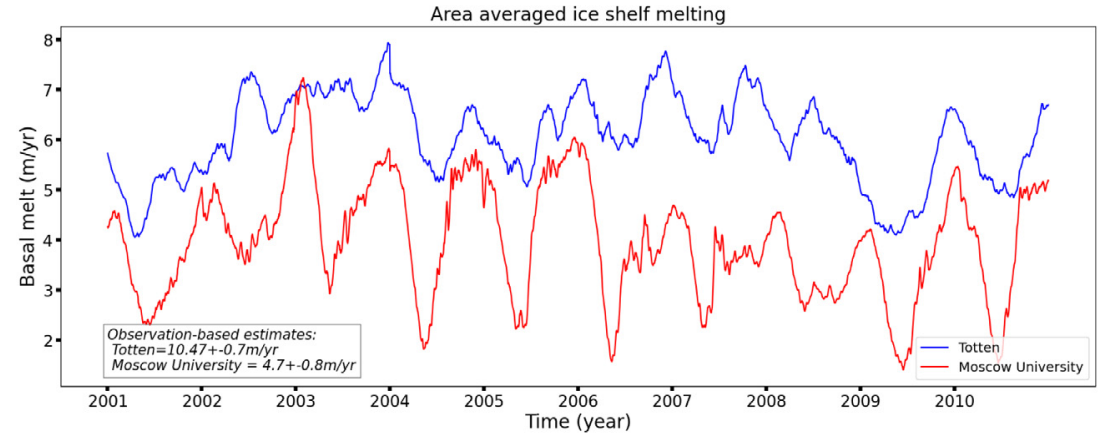

(b)

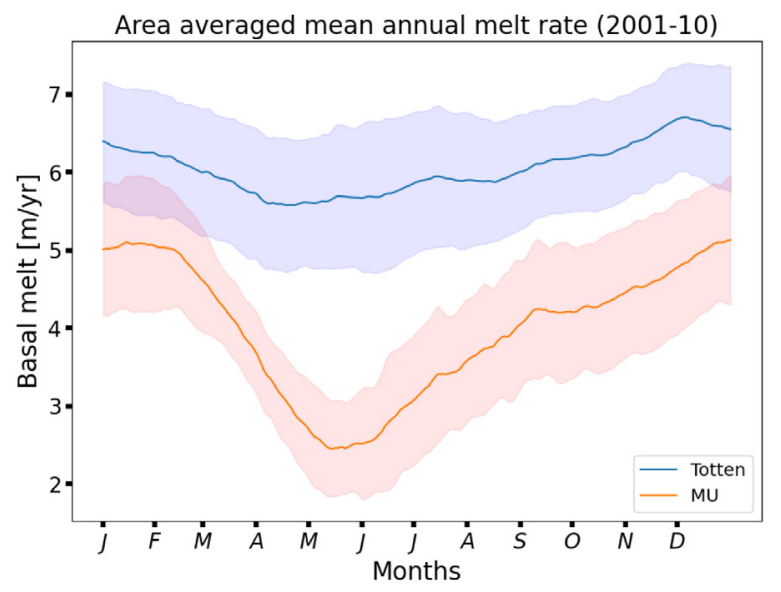

Fig. 7. Area averaged basal melt rate of the Totten (blue) and Moscow University (red) ice shelves (a), and its mean annual cycle (b).

$0.7^{\circ} \mathrm{C}$ lower in summer than in winter Fig. 8c). During winter, the ASC zonal component is reduced (meridional arrows across the ASF), which both decreases the import of cold water from the east and increases the amount of mCDW reaching the MUIS front (Fig. 8d).

Sea ice production and melt can also interfere in different ways with the basal melt. In the presence of fast ice, sea ice melting is enhanced in summer, and the sea ice production is dampened in winter (in areas along the coast, shown in Section 4). Consequently, the fast ice leads to shallower MLD and a more stratified thermocline, which increases warm water intrusion into the cavities. On the other hand, in polynyas, High Salinity Shelf Water (HSSW) is produced through local intense sea ice production, disturbing the ocean circulation near the coast (Nakayama et al., 2021) and decreasing the melt rate. 
(a)

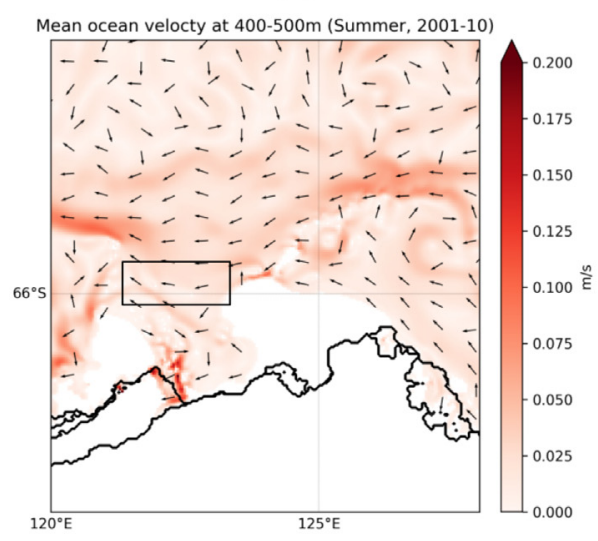

(c)

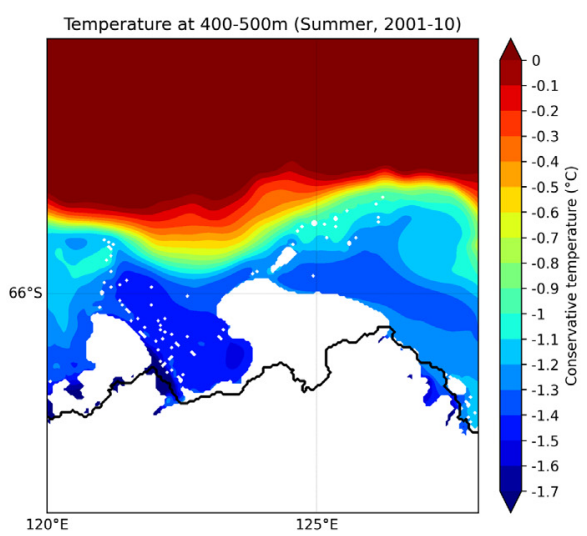

(b)

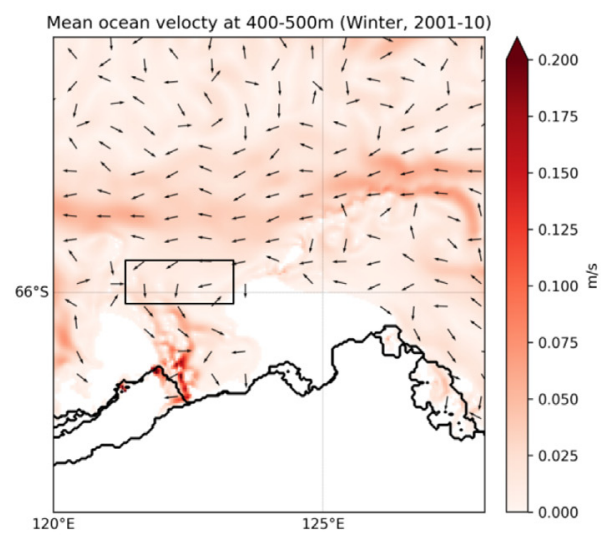

(d)

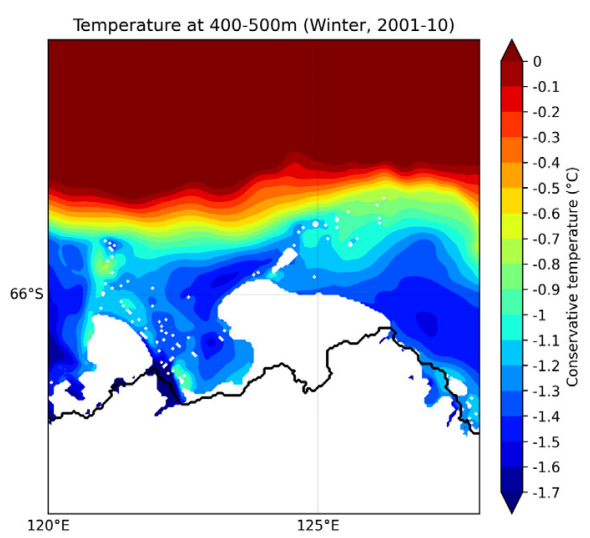

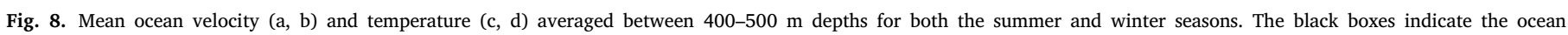
velocity over the continental slope.

\section{Representation of landfast sea ice in the sensitivity experiments}

In this section, we describe the sea ice changes resulting from the implementation of the two parameterisations responsible for fast ice production (sea ice tensile strength parameterisation and representation of grounded icebergs). We evaluate the sensitivity of the fast ice to the tensile strength parameterisation and the presence of icebergs (Fig. 9). On the one hand, compared to the noALL simulation, the inclusion of the sea ice tensile strength (TENS) only slightly improves the fast ice frequency along the coast due to ice arching formation. On the other hand, the presence of icebergs alone (ICB) yields no improvement in terms of fast ice occurrence. Solely the combination of both icebergs and tensile strength (REF) leads to a satisfactory fast ice representation. Fast ice forms where sea ice is blocked by icebergs or by ice arching created between icebergs. The fast ice is then thickened by thermodynamical growth, sea ice advection or snow-ice formation resulting from snow accumulation.

Fig. 10 shows the simulated polynya frequency for all four simulations. As in Massom et al. (2001), Nihashi and Ohshima (2015) and Fraser et al. (2019), Fig. 10 reveals that the blocking effect of the fast ice on the westward advection of sea ice by the coastal current or easterly wind is a key factor for the formation of polynyas. Indeed, no open-ocean polynya (the ones detached from the coast) is simulated in neither the ICB, TENS or noALL simulations. This pinpoints the importance of adequate fast ice representation in order to simulate ocean polynyas and correctly reproduce their locations.

Fig. 11 displays the patterns of sea ice production at different locations depending on the presence of fast ice, and illustrates the relationship between sea ice production and polynyas. Due to the absence of fast ice along the coast, the ICB, TENS and noALL simulations produce more sea ice close to the coast, with an increase of $5 \mathrm{~m} / \mathrm{yr}$ of sea ice production along the Totten coast and more than $8 \mathrm{~m} / \mathrm{yr}$ along the Moscow University coast (depicted by the negative values in Fig. 11). In REF, due to the presence of fast ice and its ability to isolate the ocean from the atmosphere, most of the main production zones are shifted offshore, where fast ice enhances polynya activity. At the location of these offshore polynyas, almost no sea ice is produced in the simulations without fast ice, which is shown by the sea ice production anomaly reaching more than $8 \mathrm{~m} / \mathrm{yr}$. The total sea ice production in REF is $21 \%$ higher than in noALL, which is consistent with the larger number of polynyas in REF.

\section{Sensitivity of basal melt to landfast sea ice}

In this section, we investigate the sensitivity of the basal melt of the Totten and Moscow University ice shelves to the presence of fast ice. Since fast ice is reasonably simulated only when the sea ice tensile strength parameterisation is combined with the inclusion of grounded icebergs in the model, only the REF and noALL simulations are considered. Fig. 12 shows the area-averaged simulated basal melt rates of the Totten (a) and Moscow University (b) ice shelves. The presence of fast ice (in blue) increases TIS melt rate by $+16 \%$ on average and the MUIS melt rate by $+10 \%$ on average, but with a $+54 \%$ increase during winter.

Hereafter, we analyse this impact on both cavities separately. As illustrated in Fig. 11c, the Moscow University region is strongly influenced by the fast ice through the displacement of the sea ice production area. Without fast ice, a large band of high sea ice production is present near the coast in front and on the eastern side of the MUIS. This results 
(a) REF

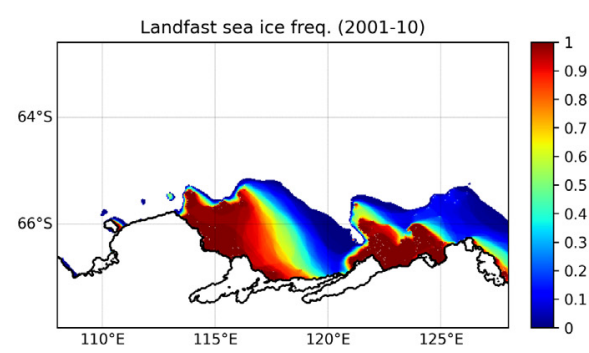

(c) TENS

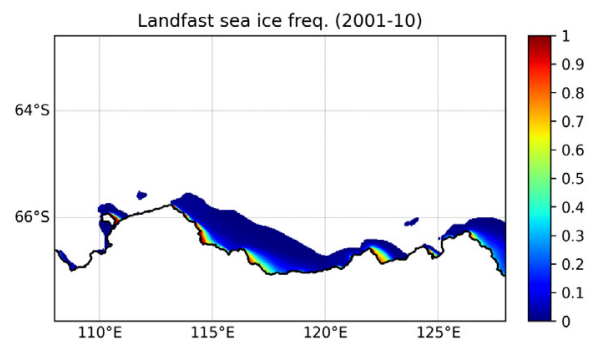

(b) ICB

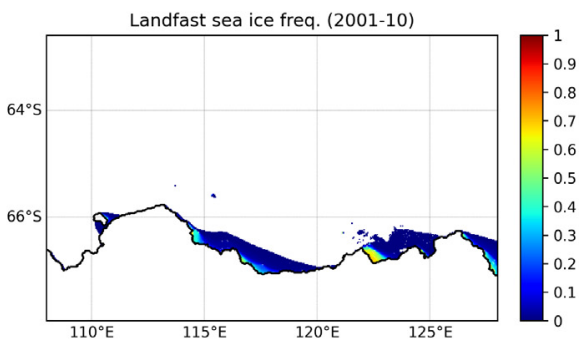

(d) noALL

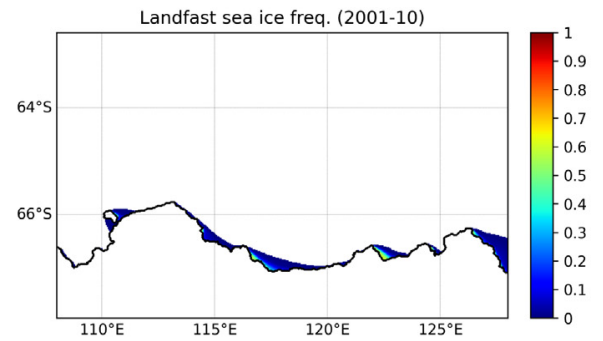

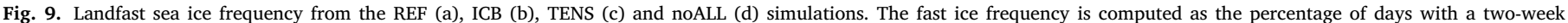
sea ice velocity lower than $0.005 \mathrm{~m} / \mathrm{s}$.

(a) REF

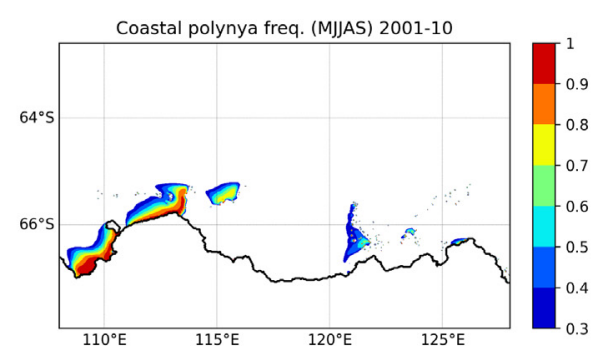

(c) TENS

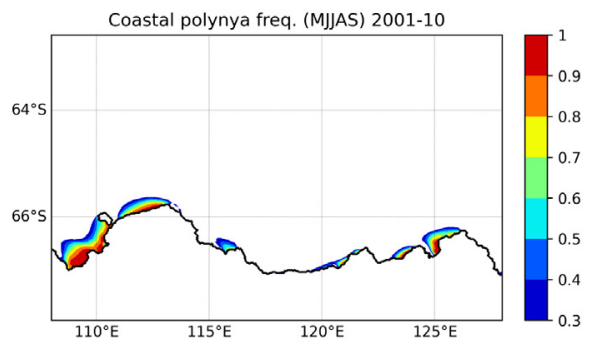

(b) ICB

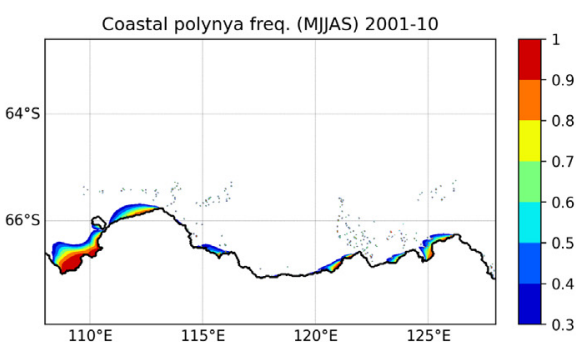

(d) noALL

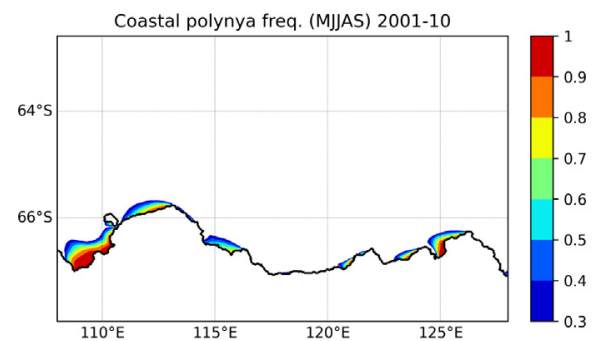

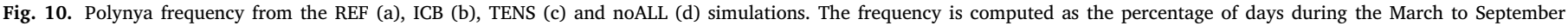
period with polynya occurrence.

in high salinity water production, which enhances ocean convection, as evidenced by the deeper MLD (Fig. 13b - less than $120 \mathrm{~m}$ in REF and more than $250 \mathrm{~m}$ in noALL), and weakens the thermocline stratification (Fig. 14d). As a consequence, warm water intrusions into the cavity are expected to be inhibited, and melt to be reduced. With fast ice, the large band of high sea ice production located along the coast in noALL is covered by fast ice, which isolates the ocean from the atmosphere and reduces the sea ice production close to the coast. Moreover, the sea ice production zones are displaced offshore, on the western side of fast ice. Those changes weaken sea ice production and ocean convection in front of the Moscow University cavity, which can favour the intrusion of more mCDW into the cavity and higher melting rates.
In addition to the lower sea ice production, the fast ice melting can partly explain the shallower mixed layers. Indeed, without fast ice, part of the sea ice is advected outside the domain during the summer season. However, because of the fast ice blocking effect, more sea ice is maintained inside the domain and the amount of sea ice melt is increased, which tends to decrease the MLD. Furthermore, Fig. 13 shows that the MLD in the REF sea ice production zones at the Dalton Polynya (Fig. 3f) is not as deep as in the noALL coastal polynyas. This suggests that, even though offshore polynyas produce more sea ice (Fig. 11c), brine rejection spreads more rapidly away than in coastal polynyas and thus has less impact on vertical mixing. 
(a) REF-ICB

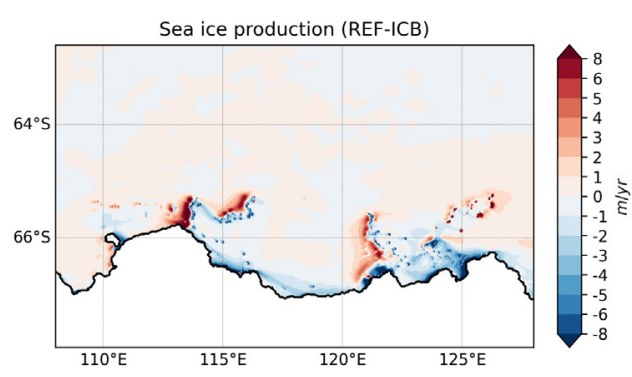

(b) REF-TENS

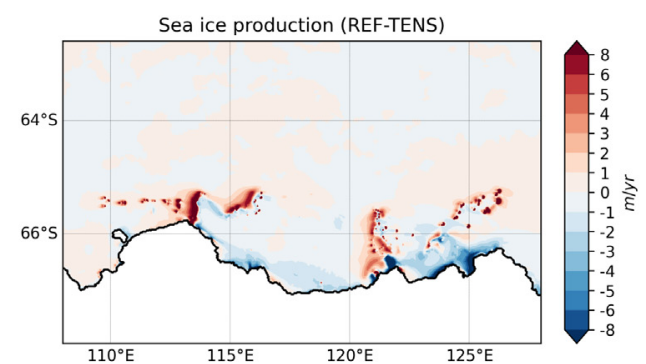

(c) REF-noALL

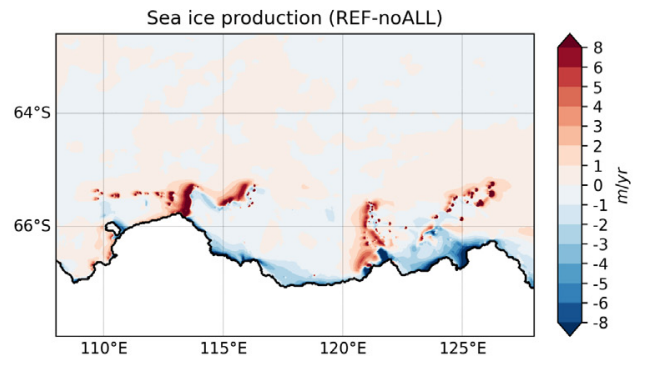

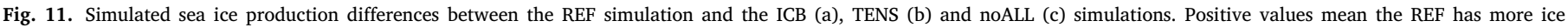
production compared to the other simulations.

(a) Totten basal melt

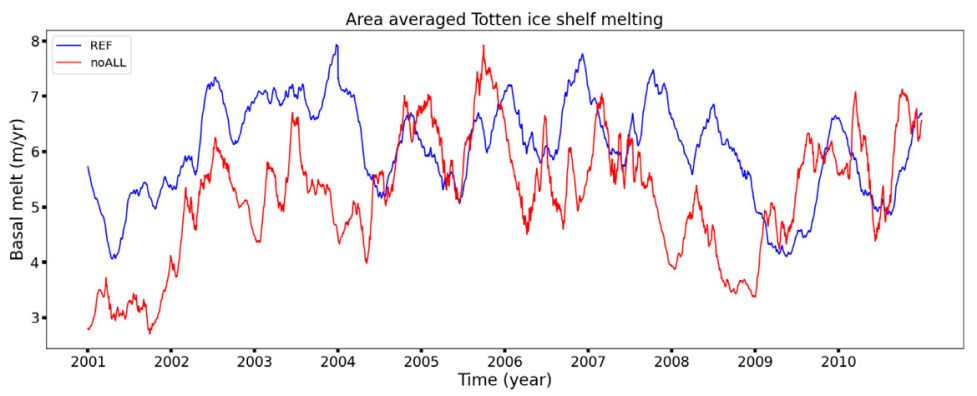

(b) Moscow University basal melt

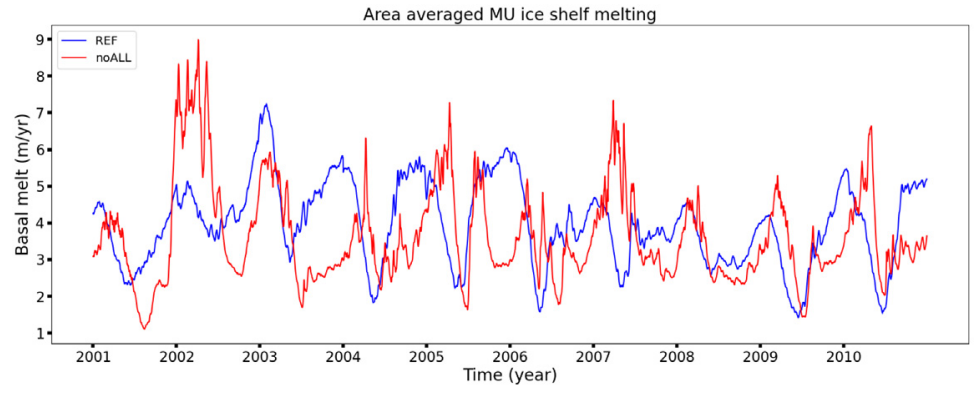

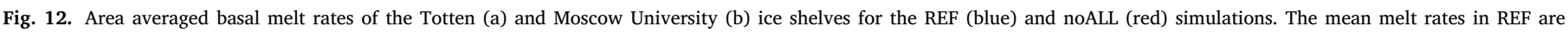

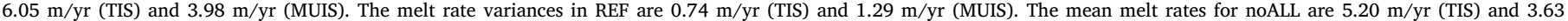
$\mathrm{m} / \mathrm{yr}$ (MUIS). The melt rate variances in noALL are $1.19 \mathrm{~m} / \mathrm{yr}$ (TIS) and $1.73 \mathrm{~m} / \mathrm{yr}$ (MUIS).

Fig. 14 presents temperature and salinity profiles in front of the MUIS for both the REF and noALL simulations. The ocean top layer in the REF simulation is fresher compared to the noALL experiment during both summer and winter. This decrease in WW layer thickness, caused by a large reduction of total sea ice production in front of the cavity $(-46 \%$ of sea ice production in front of the MUIS in REF compared to noALL), leads to a shallower mixed layer and a more stratified thermocline in front of the cavity. Regarding temperature, the ocean bottom layers are warmer by almost $0.8^{\circ} \mathrm{C}$ in REF compared to noALL. The warming of the ocean bottom layers is intensified during winter, which is associated with the higher MUIS melt rate during winter in REF (Fig. 12b). Furthermore, the warming of the ocean bottom layers 
(a) REF

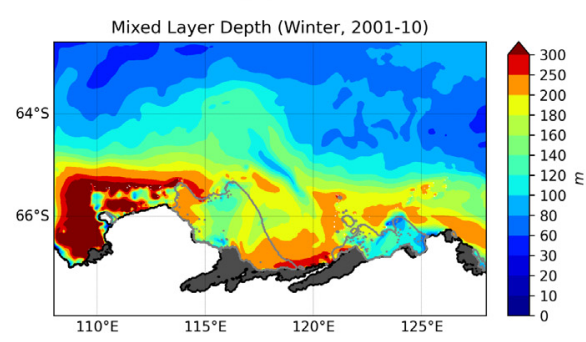

(b) noALL

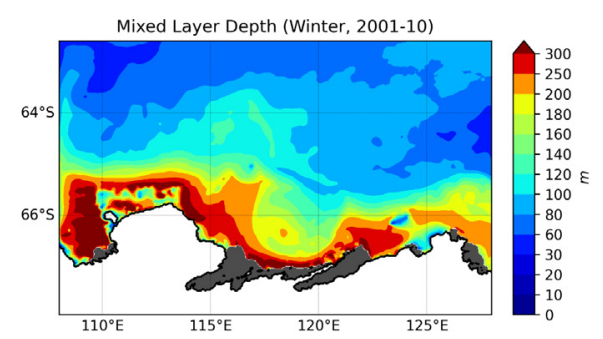

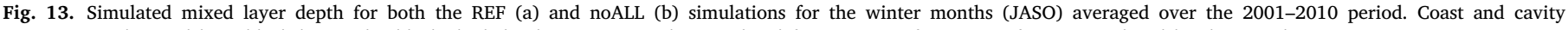
contours are depicted by a black line and a black shaded colour, respectively. Simulated fast ice area (frequency of 0.7 ) is enclosed by the grey line.

(a) REF - Moscow University

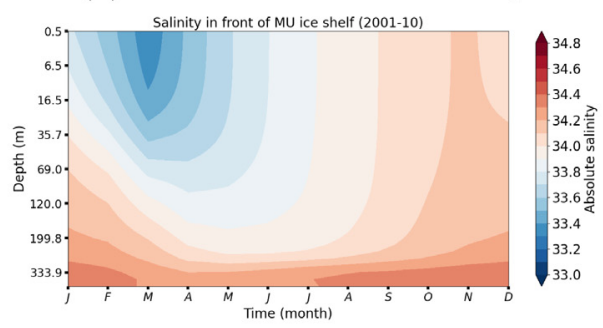

(c) REF - Moscow University

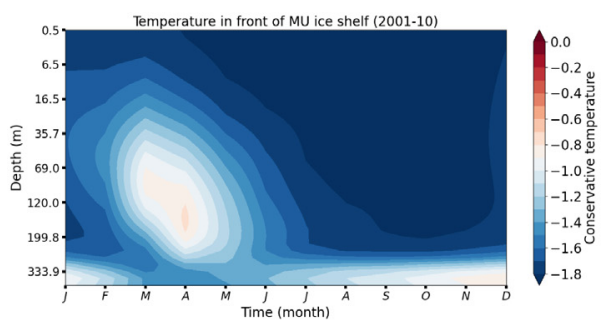

(b) noALL - Moscow University

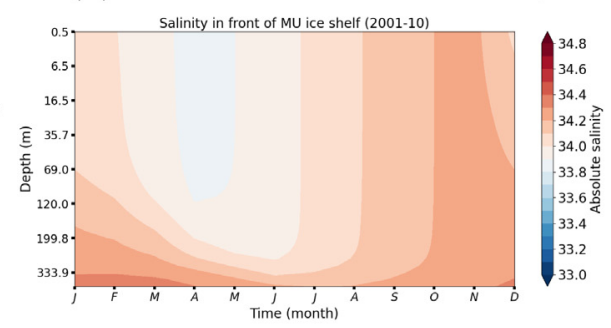

(d) noALL - Moscow University

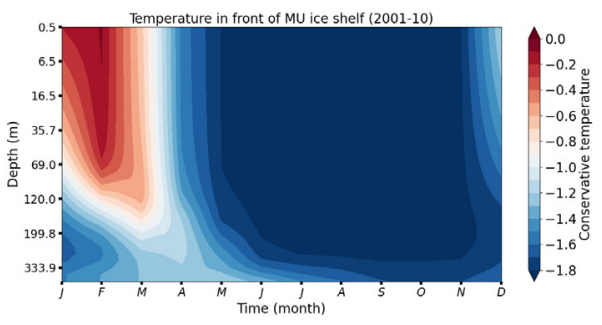

Fig. 14. Simulated absolute salinity and conservative temperature profiles (from the surface to the bottom) in front of the MUIS for both the REF and noALL simulations.

covers a broader period in REF (from October to January) than in noALL (April), which is well related to the broader MUIS melt rate peak in REF (Fig. 12b).

Finally, we assess the sensitivity of the TIS basal melt rate to the presence of fast ice. Fig. 15 depicts the temperature and salinity profiles in front of the TIS for both the REF and noALL experiments. With fast ice, the salinity in the ocean top layers decreases during both the summer and winter months. This may be due to increased sea ice melt in summer and a large decrease of sea ice production in front of the TIS cavity during winter $(-51 \%$ of sea ice production in front of the TIS in REF compared to noALL Fig. 11c). As for MUIS, the REF surface temperatures are lower in summer due to the isolating property of fast ice. The MLD is shallower (mostly during the summer and early fall) and the ocean bottom layers are slightly warmer $\left(+0.2^{\circ} \mathrm{C}\right)$ than in noALL, which is associated with the higher TIS melt rate in REF (Fig. 12a).

\section{Discussion and conclusions}

The first aim of this study was to define modelling choices allowing the first realistic representation of the fast ice in the Southern Ocean. In our case, this translated into assessing the roles of both the icebergs and sea ice tensile strength parameterisation in the formation of fast ice. To do so, we analysed the sensitivity of fast ice frequency, polynya activity and the sea ice production to the representation of icebergs and sea ice tensile strength. We ran four high-resolution simulations with the ocean-sea ice model NEMO-LIM over the Totten Glacier region. Our experiments revealed that only the combination of both the icebergs and tensile strength parameterisation leads to a fast ice cover matching observations, resulting in realistic polynya locations and sea ice production. This fast ice production can be attributed to the interactions between ice arching and icebergs. Correctly reproducing fast ice improves the simulation of sea ice production, especially in the vicinity of offshore polynyas created on the western side of fast ice.

The second goal of this study was to investigate the impact of fast ice on the basal melt of both Totten and Moscow University ice shelves. The presence of fast ice favours the intrusion of warm water into both Totten and Moscow University cavities. The ice shelves are mostly impacted by the fast ice through the displacement of the sea ice production zones from coastal to offshore areas. With less sea ice production and more sea ice melt (because of the blocking effect of the fast ice), the ocean in front of the cavity is more stratified, which favours warm water intrusion all year long. Consequently, the presence of fast ice increases the MUIS melt rate by $10 \%$ on average with a $54 \%$ increase in winter. On the other hand, for the TIS cavity, the presence of fast ice increases the basal melt rate by $16 \%$ on average.

One of the main limitations of our study lay in the large biases of the TIS melt rate and of the ocean salinity. To test the potential influence of those biases on our conclusions, sensitivity experiments (with a higher top ice sheet - ocean drag coefficient inside the cavities) have been carried out and revealed that the TIS melt rate sensitivity to fast ice depends on both TIS and MUIS melt rates mean state. Indeed, when tuning our model so that the TIS melt rate $(9.28 \mathrm{~m} / \mathrm{yr})$ gets closer to the observation-based estimate of Rignot et al. (2008), the TIS melt rate is decreased by $18 \%$ because of the presence of fast ice. This simulation is not analysed in detail here since the higher TIS melt rate could only be 
(a) REF - Totten

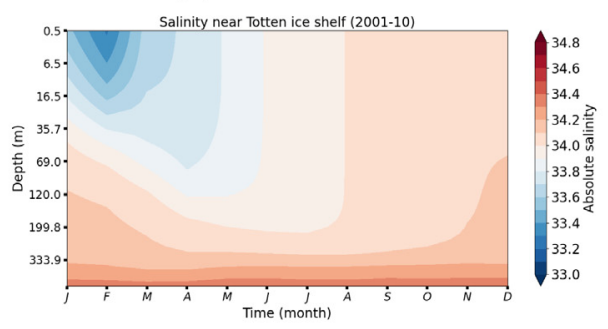

(c) REF - Totten

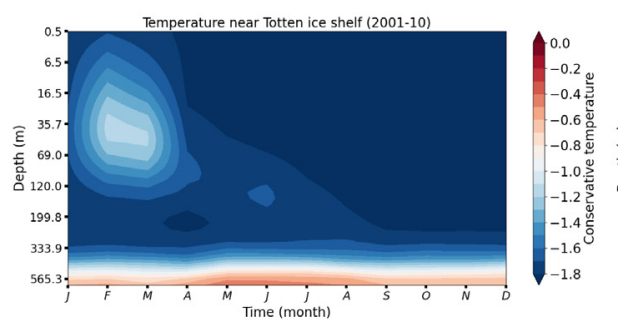

(b) noALL - Totten

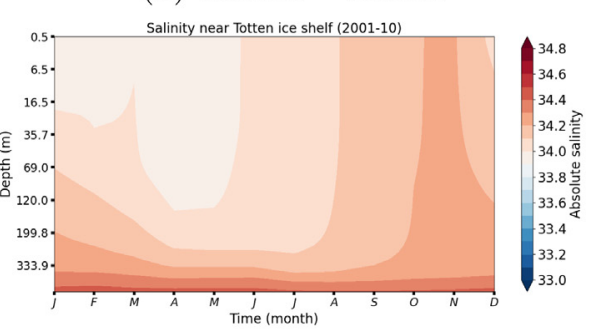

(d) noALL - Totten

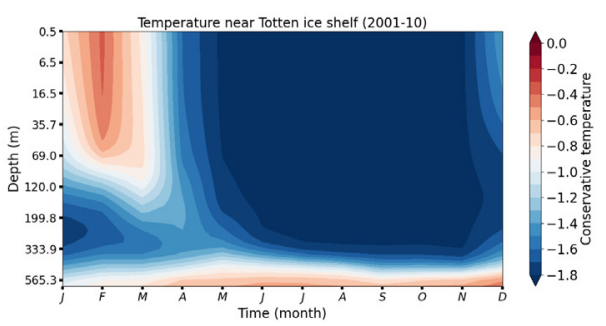

Fig. 15. Simulated absolute salinity and conservative temperature profiles (from the surface to the bottom) in front of the TIS for both the REF and noALL simulations.

achieved at the cost of a strongly overestimated MUIS melt rate $(11.12$ $\mathrm{m} / \mathrm{yr}$ ), and a much larger ocean salinity bias over the shelf. This tuning is thus not a solution to reduce the biases, but obtaining simultaneously reasonable melt rates in distinct cavities, displaying different geometry, is a considerable challenge in idealised settings (Favier et al., 2019), and even more so in realistic ones (Jourdain et al., 2020; Lipscomb et al., 2021; Burgard and Jourdain, 2021), especially in the Totten area (Khazendar et al., 2013; Gwyther et al., 2014). Moreover, this shows that fast ice could also indirectly decrease the melt rate of an ice shelf, under the condition that for two nearby ice shelves, the eastern ice shelf has a large melt rate increase due to the fast ice and that the resulting meltwater outflow inhibits the melt rate of the western ice shelf. Other sensitivity experiments with unprocessed bathymetry and ice draft from BedMachine (Morlighem et al., 2020) have been carried out but without any improvement of the TIS melt rate bias. Moreover, our results suggest how fast ice can strongly and variously affect ice shelf cavity melt rate, and also shows the importance of incorporating fast ice parameterisations into our future climate model.

Despite the presence of those biases in our simulated fast ice and sea ice thickness, the combination of the sea ice tensile strength parameterisation with icebergs has shown a certain capacity to simulate fast ice in a high-resolution model. Furthermore, our results underline that, in order to simulate realistic ocean-ice shelf processes in East Antarctica, accurate iceberg positions and high-resolution bathymetry datasets are required. Misplaced icebergs or overly smooth bathymetry may lead to unrealistic water masses interacting with the mCDW, thus degrading ice shelf melt rates. One perspective for further similar studies would be to simulate dynamical icebergs instead of prescribing fixed locations. In the meantime, year-to-year evolving iceberg location datasets could allow a better representation of the interannual fast ice variability. Since including a prognostic fast ice representation can strongly impact ocean circulation and the intrusion of warmer water into the cavities, applying our fast ice implementation to other regions harbouring low interannual fast ice variability may lead to interesting results. For future climate simulations, as Antarctic temperatures are expected to progressively increase, the spatial distribution of icebergs, and thus fast ice, could strongly change. Through its impact on ice shelf melt rate, including a suitable fast ice representation within climate models may yield significant advances in the understanding of the Antarctic climate.

\section{CRediT authorship contribution statement}

Guillian Van Achter: Designed the science plan with Thierry Fichefet and Hugues Goosse, Built the local configuration of NEMO-LIM in the Totten region and implemented the fast ice parameterisation with the help of Charles Pelletier, Pierre-Vincent Huot and Jean Sterlin, Conducted the data processing, Ran the simulations, Produced the figures, Analysed the results and wrote the manuscript based on insights from all co-authors. Jean-François Lemieux: Helped with the choice of parameters for the fast ice, Helped to analyse the simulated fast ice results. Alexander D. Fraser: Provided the fast ice observational dataset, Helped to analyse the simulated fast ice results. Konstanze Haubner: Provided the bathymetry dataset. Richard Porter-Smith: Provided the icebergs dataset.

\section{Declaration of competing interest}

The authors declare that they have no known competing financial interests or personal relationships that could have appeared to influence the work reported in this paper.

\section{Acknowledgements}

This project (EOS O0100718F) has received funding from the FWO, Belgium and F.R.S.-FNRS, Belgium under the Excellence of Science (EOS) programme. HG is research director with the F.R.S-FNRS (Belgium). Computational resources have been provided by the supercomputing facilities of the Université catholique de Louvain (CISM/UCL) and the Consortium des Equipements de Calcul Intensif en Fédération Wallonie Bruxelles (CECI) funded by the Fond de la Recherche Scientifique de Belgique, Belgium (F.R.S.-FNRS) under convention 2.5020.11. The present research benefited from computational resources made available on the Tier-1 supercomputer of the Fédération WallonieBruxelles, infrastructure funded by the Walloon Region under the grant agreement n1117545. This project received grant funding from the Australian Government as part of the Antarctic Science Collaboration Initiative program. The marine mammal data were collected and made freely available by the International MEOP Consortium and the national programs that contribute to it (http://www.meop.net). This study has been conducted using E.U. Copernicus Marine Service Information.

\section{References}

Adcroft, A., Hill, C., Marshall, J., 1997. Representation of topography by shaved cells in a height coordinate ocean model. Mon. Weather Rev. 125 (9), 2293-2315. http://dx.doi.org/10.1175/1520-0493(1997)125<2293:ROTBSC > 2.0.CO;2. 
Aitken, A.R.A., Roberts, J.L., Ommen, T.D.v., Young, D.A., Golledge, N.R., Greenbaum, J.S., Blankenship, D.D., Siegert, M.J., 2016. Repeated large-scale retreat and advance of Totten Glacier indicated by inland bed erosion. Nature 533 (7603), 385-389. http://dx.doi.org/10.1038/nature17447.

Barthélemy, A., Goosse, H., Fichefet, T., Lecomte, O., 2018. On the sensitivity of antarctic sea ice model biases to atmospheric forcing uncertainties. Clim. Dyn. 51, 1585-1603. http://dx.doi.org/10.1007/s00382-017-3972-7.

Bitz, C.M., Holland, M.M., Weaver, A.J., Eby, M., 2001. Simulating the ice-thickness distribution in a coupled climate model. J. Geophys. Res. Oceans 106 (C2), 2441-2463. http://dx.doi.org/10.1029/1999JC000113.

Bougeault, P., Lacarrere, P., 1989. Parameterization of orography-induced turbulence in a mesobeta-scale model. Mon. Weather Rev. 117 (8), 1872-1890. http://dx.doi. org/10.1175/1520-0493(1989)117<1872:POOITI > 2.0.CO;2.

Burgard, C., Jourdain, N., 2021. An assessment of basal melting parameterisations for Antarctic ice shelves. http://dx.doi.org/10.5194/egusphere-egu21-1367.

Carrère, L., Lyard, F., Cancet, M., Guillot, A., Roblou, L., 2012. A new global tidal model taking taking advantage of nearly 20 years of altimetry. In: Proceedings of Meeting "20 Years of Altimerty". URL https://ui.adsabs.harvard.edu/abs/2013ESASP.710E. .13C/abstract.

Dansereau, V., Heimbach, P., Losch, M., 2014. Simulation of subice shelf melt rates in a general circulation model: Velocity-dependent transfer and the role of friction. J. Geophys. Res. Oceans 119 (3), 1765-1790. http://dx.doi.org/10.1002/ 2013JC008846.

Engedahl, H., 1995. Use of the flow relaxation scheme in a three-dimensional baroclinic ocean model with realistic topography. Tellus 47 (3), 365-382. http://dx.doi.org/ 10.3402/tellusa.v47i3.11523.

Favier, L., Jourdain, N.C., Jenkins, A., Merino, N., Durand, G., Gagliardini, O., GilletChaulet, F., Mathiot, P., 2019. Assessment of sub-shelf melting parameterisations using the ocean-ice-sheet coupled model NEMO(v3.6)-Elmer/Ice(v8.3). Geosci. Model Dev. 12 (6), 2255-2283. http://dx.doi.org/10.5194/gmd-12-2255-2019.

Flather, R.A., 1994. A storm surge prediction model for the northern bay of bengal with application to the cyclone disaster in april 1991. J. Phys. Oceanogr. 24 (1), 172-190. http://dx.doi.org/10.1175/1520-0485(1994)024<0172:ASSPMF>2.0.CO; 2.

Fraser, A.D., Massom, R.A., Michael, K.J., Galton-Fenzi, B.K., Lieser, J.L., 2012. East antarctic landfast sea ice distribution and variability, 2000-08. J. Clim. 25 (4), 1137-1156. http://dx.doi.org/10.1175/JCLI-D-10-05032.1.

Fraser, A.D., Massom, R.A., Ohshima, K.I., Willmes, S., Kappes, P.J., Cartwright, J., Porter-Smith, R., 2020. High-resolution mapping of circum-antarctic landfast sea ice distribution, 2000-2018. Earth Syst. Sci. Data 12 (4), 2987-2999. http://dx. doi.org/10.5194/essd-12-2987-2020.

Fraser, A.D., Ohshima, K.I., Nihashi, S., Massom, R.A., Tamura, T., Nakata, K., Williams, G.D., Carpentier, S., Willmes, S., 2019. Landfast ice controls on sea-ice production in the cape darnley polynya: A case study. Remote Sens. Environ. 233, 111315. http://dx.doi.org/10.1016/j.rse.2019.111315.

Gaspar, P., Grégoris, Y., Lefevre, J.-M., 1990. A simple eddy kinetic energy model for simulations of the oceanic vertical mixing: Tests at station papa and longterm upper ocean study site. J. Geophys. Res. Oceans 95 (C9), 16179-16193. http://dx.doi.org/10.1029/JC095iC09p16179.

Giles, A.B., Massom, R.A., Lytle, V.I., 2008. Fast-ice distribution in east antarctica during 1997 and 1999 determined using RADARSAT data. J. Geophys. Res. Oceans 113 (C2), http://dx.doi.org/10.1029/2007JC004139.

Greene, C.A., Young, D.A., Gwyther, D.E., Galton-Fenzi, B.K., Blankenship, D.D., 2018. Seasonal dynamics of Totten Ice Shelf controlled by sea ice buttressing. Cryosphere 12 (9), 2869-2882. http://dx.doi.org/10.5194/tc-12-2869-2018.

Guerreiro, K., Fleury, S., Zakharova, E., Kouraev, A., Rémy, F., Maisongrande, P., 2017. Comparison of CryoSat-2 and ENVISAT radar freeboard over Arctic sea ice: toward an improved Envisat freeboard retrieval. Cryosphere 11 (5), 2059-2073. http://dx.doi.org/10.5194/tc-11-2059-2017.

Gwyther, D.E., Galton-Fenzi, B.K., Hunter, J.R., Roberts, J.L., 2014. Simulated melt rates for the Totten and Dalton ice shelves. Ocean Sci. 10 (3), 267-279. http: //dx.doi.org/10.5194/os-10-267-2014.

Gwyther, D.E., O'Kane, T.J., Galton-Fenzi, B.K., Monselesan, D.P., Greenbaum, J.S., 2018. Intrinsic processes drive variability in basal melting of the Totten Glacier Ice Shelf. Nature Commun. 9 (3141), http://dx.doi.org/10.1038/s41467-018-05618-2.

Hersbach, H., Bell, B., Berrisford, P., Hirahara, S., Horányi, A., Muñoz-Sabater, J., Nicolas, J., Peubey, C., Radu, R., Schepers, D., Simmons, A., Soci, C., Abdalla, S., Abellan, X., Balsamo, G., Bechtold, P., Biavati, G., Bidlot, J., Bonavita, M., De Chiara, G., Dahlgren, P., Dee, D., Diamantakis, M., Dragani, R., Flemming, J., Forbes, R., Fuentes, M., Geer, A., Haimberger, L., Healy, S., Hogan, R.J., Hólm, E., Janisková, M., Keeley, S., Laloyaux, P., Lopez, P., Lupu, C., Radnoti, G., de Rosnay, P., Rozum, I., Vamborg, F., Villaume, S., Thépaut, J.-N., 2020. The ERA5 global reanalysis. Q. J. R. Meteorol. Soc. 146 (730), 1999-2049. http://dx.doi.org/ 10.1002/qj.3803.

Hunke, E.C., 2001. Viscous-plastic sea ice dynamics with the EVP model: Linearization issues. J. Comput. Phys. 170 (1), 18-38. http://dx.doi.org/10.1006/jcph.2001. 6710.
Huot, P.-V., Fichefet, T., Jourdain, N.C., Mathiot, P., Rousset, C., Kittel, C., Fettweis, X. 2021. Influence of ocean tides and ice shelves on ocean-ice interactions and dense shelf water formation in the D'urville Sea, Antarctica. Ocean Model. 162, 101794. http://dx.doi.org/10.1016/j.ocemod.2021.101794, URL https://www.sciencedirect. com/science/article/pii/S1463500321000445.

Itkin, P., Losch, M., Gerdes, R., 2015. Landfast ice affects the stability of the arctic halocline: Evidence from a numerical model. J. Geophys. Res. Oceans 120 (4), 2622-2635. http://dx.doi.org/10.1002/2014JC010353.

Jenkins, A., 1991. A one-dimensional model of ice shelf-ocean interaction. J. Geophys. Res. 96 (C11), 20671-20677. http://dx.doi.org/10.1029/91JC01842.

Jezek, K.C., Curlander, J.C., Carsey, F., Wales, C., Barry, R.G., 2013. RAMP AMM-1 SAR Image Mosaic of Antarctica, Version 2. [Indicate subset used]. NASA National Snow and Ice Data Center Distributed Active Archive Center, Boulder, Colorado USA, http://dx.doi.org/10.5067/8AF4ZRPULS4H.

Johnson, M., Proshutinsky, A., Aksenov, Y., Nguyen, A.T., Lindsay, R., Haas, C., Zhang, J., Diansky, N., Kwok, R., Maslowski, W., Häkkinen, S., Ashik, I., de Cuevas, B., 2012. Evaluation of arctic sea ice thickness simulated by arctic ocean model intercomparison project models. J. Geophys. Res. Oceans 117 (C8), http://dx.doi.org/10.1029/2011JC007257.

Jourdain, N.C., Asay-Davis, X., Hattermann, T., Straneo, F., Seroussi, H., Little, C.M., Nowicki, S., 2020. A protocol for calculating basal melt rates in the ISMIP6 antarctic ice sheet projections. Cryosphere 14 (9), 3111-3134. http://dx.doi.org/ 10.5194/tc-14-3111-2020.

Jourdain, N.C., Mathiot, P., Merino, N., Durand, G.A.l., Le Sommer, J., Spence, P., Dutrieux, P., Madec, G., 2017. Ocean circulation and sea-ice thinning induced by melting ice shelves in the amundsen sea. J. Geophys. Res. Oceans 122 (3), 2550-2573. http://dx.doi.org/10.1002/2016JC012509.

Jourdain, N.C., Molines, J.-M., Le Sommer, J., Mathiot, P., Chanut, J., de Lavergne, C., Madec, G., 2019. Simulating or prescribing the influence of tides on the Amundsen Sea ice shelves. Ocean Model. 133, 44-55. http://dx.doi.org/10.1016/j.ocemod. 2018.11.001.

Kern, S., 2012. Antarctic daily winter-time polynya distribution from SSM/I brightness temperature data. In: Integrated Climate Data Center (ICDC). CEN, University of Hamburg, Hamburg, Germany, Digital Media, URL http://icdc.cen.uni-hamburg.de/ polynya_ant.html.

Khazendar, A., Schodlok, M., Fenty, I., Ligtenberg, S., Rignot, E., van den Broeke, M., 2013. Observed thinning of Totten Glacier is linked to coastal polynya variability. Nature Commun. 4 (2857), http://dx.doi.org/10.1038/ncomms3857.

König Beatty, C., Holland, D.M., 2010. Modeling landfast sea ice by adding tensile strength. J. Phys. Oceanogr. 40 (1), 185-198. http://dx.doi.org/10.1175/ 2009JPO4105.1.

Kusahara, K., Hasumi, H., Fraser, A.D., Aoki, S., Shimada, K., Williams, G.D., Massom, R., Tamura, T., 2016. Modeling ocean-cryosphere interactions off Adélie and george v land, east antarctica. J. Clim. 30 (1), 163-188. http://dx.doi.org/10.1175/ JCLI-D-15-0808.1.

Large, W., Yeager, S., 2004. Diurnal to decadal global forcing for ocean and seaice models: the data sets and flux climatologie. UCAR http://dx.doi.org/10.5065/ D6KK98Q6.

Lemieux, J.-F., Dupont, F., Blain, P., Roy, F., Smith, G.C., Flato, G.M., 2016. Improving the simulation of landfast ice by combining tensile strength and a parameterization for grounded ridges. J. Geophys. Res. Oceans 121 (10), 7354-7368. http://dx.doi. org/10.1002/2016JC012006.

Lemieux, J.-F., Tremblay, L.B., Dupont, F., Plante, M., Smith, G.C., Dumont, D., 2015. A basal stress parameterization for modeling landfast ice. J. Geophys. Res. Oceans 120 (4), 3157-3173. http://dx.doi.org/10.1002/2014JC010678.

Lieser, J.L., 2004. A numerical model for short-term sea ice forecasting in the Arctic. (Ph.D. thesis). Universitaet Bremen, URL https://epic.awi.de/id/eprint/11592/.

Lipscomb, W., Hunke, E., Maslowski, W., Jakacki, J., 2007. Ridging, strength, and stability in high-resolution sea ice models. J. Geophys. Res. 112, http://dx.doi.org/ 10.1029/2005JC003355.

Lipscomb, W.H., Leguy, G.R., Jourdain, N.C., Asay-Davis, X., Seroussi, H., Nowicki, S., 2021. ISMIP6-based projections of ocean-forced antarctic ice sheet evolution using the community ice sheet model. Cryosphere 15 (2), 633-661. http://dx.doi.org/10. 5194/tc-15-633-2021.

Losch, M., 2008. Modeling ice shelf cavities in a $\mathrm{z}$ coordinate ocean general circulation model. J. Geophys. Res. Oceans 113 (C8), http://dx.doi.org/10.1029/ 2007JC004368.

Madec, G., 2008. NEMO Ocean Engine. Note du Pole de modelisation, Institut Pierre-Simon Laplace (IPSL), France, No 27, ISSN No 1288-1619.

Madec, G., Delecluse, P., Imbard, M., Levy, C., 1998. 1 Ocean General Circulation Model Reference Manual.

Mahoney, A., Eicken, H., Shapiro, L., 2007. How fast is landfast sea ice? A study of the attachment and detachment of nearshore ice at Barrow, Alaska. Cold Reg. Sci. Technol. 47, 233-255. http://dx.doi.org/10.1016/j.coldregions.2006.09.005.

Maraldi, C., Chanut, J., Levier, B., Ayoub, N., De Mey, P., Reffray, G., Lyard, F., Cailleau, S., Drévillon, M., Fanjul, E.A., Sotillo, M.G., Marsaleix, P., the Mercator Research and Development Team, 2013. NEMO on the shelf: assessment of the Iberiandash;Biscayndash;Ireland configuration. Ocean Sci. 9 (4), 745-771. http: //dx.doi.org/10.5194/os-9-745-2013. 
Massom, R.A., Harris, P., Michael, K.J., Potter, M., 1998. The distribution and formative processes of latent-heat polynyas in East Antarctica. Ann. Glaciol. 27, 420-426. http://dx.doi.org/10.3189/1998AoG27-1-420-426.

Massom, R.A., Hill, K.L., Lytle, V.I., Worby, A.P., Paget, M., Allison, I., 2001. Effects of regional fast-ice and iceberg distributions on the behaviour of the Mertz Glacier polynya, East Antarctica. Ann. Glaciol. 33, 391-398. http://dx.doi.org/10.3189/ 172756401781818518.

Massom, R.A., Scambos, T.A., Bennetts, L.G., Reid, P., Squire, V.A., Stammerjohn, S.E., 2018. Antarctic ice shelf disintegration triggered by sea ice loss and ocean swell. Nature 558, 383-389. http://dx.doi.org/10.1038/s41586-018-0212-1.

Massom, R.A., Stammerjohn, S.E., 2010. Antarctic sea ice change and variability Physical and ecological implications. Polar Sci. 4 (2), 149-186. http://dx.doi.org/ 10.1016/j.polar.2010.05.001.

Massonnet, F., Goosse, H., Fichefet, T., Counillon, F., 2014. Calibration of sea ice dynamic parameters in an ocean-sea ice model using an ensemble Kalman filter. J. Geophys. Res. Oceans 119 (7), 4168-4184. http://dx.doi.org/10.1002/ 2013JC009705.

Mathiot, P., Jenkins, A., Harris, C., Madec, G., 2017. Explicit representation and parametrised impacts of under ice shelf seas in the $z^{*}$ coordinate ocean model NEMO 3.6. Geosci. Model Dev. 10 (7), 2849-2874. http://dx.doi.org/10.5194/gmd10-2849-2017.

Meier, W.N., Fetterer, F., Savoie, M., Mallory, S., Duerr, R., Stroeve, J., 2017. NOAA/NSIDC Climate Data Record of Passive Microwave Sea Ice Concentration, Version 3. [Indicate subset used]. NSIDC: National Snow and Ice Data Center, Boulder, Colorado USA, URL https://nsidc.org/data/G02202/versions/3.

Morlighem, M., Rignot, E., Binder, T., Blankenship, D., Drews, R., Eagles, G., Eisen, O., Forsberg, R., Fretwell, P., Goel, V., Greenbaum, J., Gudmundsson, G., Guo, J., Helm, V., Hofstede, C., Howat, I., Humbert, A., Jokat, W., Young, D., 2020. Deep glacial troughs and stabilizing ridges unveiled beneath the margins of the Antarctic ice sheet. Nat. Geosci. 13, 1-6. http://dx.doi.org/10.1038/s41561-019-0510-8.

Nakayama, Y., Greene, C.A., Paolo, F.S., Mensah, V., Zhang, H., Kashiwase, H., Simizu, D., Greenbaum, J.S., Blankenship, D.D., Abe-Ouchi, A., Aoki, S., 2021. Antarctic slope current modulates ocean heat intrusions towards totten glacier. Geophys. Res. Lett. 48 (17), http://dx.doi.org/10.1029/2021GL094149, e2021GL094149.

Nakayama, Y., Timmermann, R., Schröder, M., Hellmer, H., 2014. On the difficulty of modeling Circumpolar Deep Water intrusions onto the Amundsen Sea continental shelf. Ocean Model. 84, 26-34. http://dx.doi.org/10.1016/j.ocemod.2014.09.007.

Nihashi, S., Ohshima, K.I., 2015. Circumpolar mapping of Antarctic Coastal polynyas and landfast sea ice: Relationship and variability. J. Clim. 28, 3650-3670. http: //dx.doi.org/10.1175/JCLI-D-14-00369.1.

Nitsche, F.O., Porter, D., Williams, G., Cougnon, E.A., Fraser, A.D., Correia, R., Guerrero, R., 2017. Bathymetric control of warm ocean water access along the east antarctic margin. Geophys. Res. Lett. 44 (17), 8936-8944. http://dx.doi.org/ 10.1002/2017GL074433.

Paolo, F.S., Fricker, H.A., Padman, L., 2015. Volume loss from Antarctic ice shelves is accelerating. Science 348 (6232), 327-331. http://dx.doi.org/10.1126/science. aaa0940.

Pelletier, C., Fichefet, T., Goosse, H., Haubner, K., Helsen, S., Huot, P.-V., Kittel, C., Klein, F., Le clec'h, S., van Lipzig, N.P.M., Marchi, S., Massonnet, F., Mathiot, P., Moravveji, E., Moreno-Chamarro, E., Ortega, P., Pattyn, F., Souverijns, N., Van Achter, G., Vanden Broucke, S., Vanhulle, A., Verfaillie, D., Zipf, L., 2021. PARASO, a circum-Antarctic fully-coupled ice-sheet - ocean - sea-ice - atmosphere - land model involving f.ETISh1.7, NEMO3.6, LIM3.6, COSMO5.0 and CLM4.5. Geosci. Model Dev. Discuss. 2021, 1-59. http://dx.doi.org/10.5194/gmd-2021-315.

Rignot, E., Bamber, J., Van den Broeke, M., Davis, C., Li, Y., Berg, W., Meijgaard, E., 2008. Recent Antarctic ice mass loss from radar interferometry and regional climate modelling. Nat. Geosci. 1, 106-110. http://dx.doi.org/10.1038/ngeo102.

Rignot, E., Jacobs, S., Mouginot, J., Scheuchl, B., 2013. Ice-shelf melting around antarctica. Science 341 (6143), 266-270. http://dx.doi.org/10.1126/science. 1235798.

Rintoul, S.R., Silvano, A., Pena-Molino, B., van Wijk, E., Rosenberg, M., Greenbaum, J.S., Blankenship, D.D., 2016. Ocean heat drives rapid basal melt of the Totten Ice Shelf. Sci. Adv. 2 (12), http://dx.doi.org/10.1126/sciadv.1601610.
Roberts, J.L., Warner, R.C., Young, D., Wright, A., van Ommen, T.D., Blankenship, D.D. Siegert, M., Young, N.W., Tabacco, I.E., Forieri, A., Passerini, A., Zirizzotti, A., Frezzotti, M., 2011. Refined broad-scale sub-glacial morphology of Aurora Subglacial Basin, East Antarctica derived by an ice-dynamics-based interpolation scheme. Cryosphere 5 (3), 551-560. http://dx.doi.org/10.5194/tc-5-551-2011.

Roquet, F., Williams, G., Hindell, M.A., Harcourt, R., McMahon, C., Guinet, C., Charrassin, J.-B., Reverdin, G., Boehme, L., Lovell, P., Fedak, M., 2014. A Southern Indian Ocean database of hydrographic profiles obtained with instrumented elephant seals. Sci. Data 1 (1), http://dx.doi.org/10.1038/sdata.2014.28.

Rousset, C., Vancoppenolle, M., Madec, G., Fichefet, T., Flavoni, S., Barthélemy, A., Benshila, R., Chanut, J., Levy, C., Masson, S., Vivier, F., 2015. The Louvain-LaNeuve sea ice model LIM3.6: global and regional capabilities. Geosci. Model Dev. 8 (10), 2991-3005. http://dx.doi.org/10.5194/gmd-8-2991-2015.

Rozman, P., Hölemann, J.A., Krumpen, T., Gerdes, R., Köberle, C., Lavergne, T., Adams, S., Girard-Ardhuin, F., 2011. Validating satellite derived and modelled seaice drift in the laptev sea with in situ measurements from the winter of $2007 / 08$. Polar Res. 30 (7218), http://dx.doi.org/10.3402/polar.v30i0.7218.

Silvano, A., Rintoul, S.R., Kusahara, K., Peña Molino, B., van Wijk, E., Gwyther, D.E., Williams, G.D., 2019. Seasonality of warm water intrusions onto the continental shelf near the totten glacier. J. Geophys. Res. Oceans 124 (6), 4272-4289. http: //dx.doi.org/10.1029/2018JC014634.

Silvano, A., Rintoul, S.R., Peña Molino, B., Williams, G.D., 2017. Distribution of water masses and meltwater on the continental shelf near the Totten and Moscow University ice shelves. J. Geophys. Res. Oceans 122 (3), 2050-2068. http://dx.doi. org/10.1002/2016JC012115.

St-Laurent, P., Yager, P.L., Sherrell, R.M., Stammerjohn, S.E., Dinniman, M.S., 2017. Pathways and supply of dissolved iron in the Amundsen Sea (Antarctica). J. Geophys. Res. Oceans 122 (9), 7135-7162. http://dx.doi.org/10.1002/ 2017JC013162.

Tamura, T., Ohshima, K.I., Fraser, A.D., Williams, G.D., 2016. Sea ice production variability in Antarctic coastal polynyas. J. Geophys. Res. Oceans 121 (5), 2967-2979. http://dx.doi.org/10.1002/2015JC011537.

Tamura, T., Ohshima, K.I., Nihashi, S., 2008. Mapping of sea ice production for Antarctic coastal polynyas. Geophys. Res. Lett. 35 (7), http://dx.doi.org/10.1029/ 2007 GL032903.

Treasure, A.M., Roquet, F., Ansorge, I.J., Bester, M.N., Horst Bornemann, L.B., Charrassin, J.-B., Chevallier, D., Costa, D.P., Fedak, M.A., Guinet, C., Hammill, M.O., Harc ourt, R.G., Hindell, M.A., Kovacs, K.M., Lea, M.-A., Lovell, P., Lowther, A.D., Lydersen, C., McIntyre, T., McMahon, C.R., Muelbert, M.M.C., Nicholls, K., Picard, B., Reverdi n, G., Trites, A.W., Williams, G.D., de Bruyn, P.J.N., 2017. Marine mammals exploring the oceans pole to pole: A review of the MEOP consortium. Oceanograph issue_volume, http://dx.doi.org/10.5670/oceanog.2017.234.

Ushio, S., 2006. Factors affecting fast-ice break-up frequency in Lutzow-Holm Bay, Antarctica. Ann. Glaciol. 44 (1), 177-182. http://dx.doi.org/10.3189/ 172756406781811835 .

Vancoppenolle, M., Fichefet, T., Goosse, H., Bouillon, S., Madec, G., Maqueda, M., 2009. Simulating the mass balance and salinity of Arctic and Antarctic sea ice. 1 . Model description and validation. Ocean Model. 27 (1), 33-53. http://dx.doi.org/ 10.1016/j.ocemod.2008.10.005.

Wadhams, P., Lange, M.A., Ackley, S.F., 1987. The ice thickness distribution across the Atlantic sector of the Antarctic Ocean in midwinter. J. Geophys. Res. Oceans 92 (C13), 14535-14552. http://dx.doi.org/10.1029/JC092iC13p14535.

Wang, J., Mizobata, K., Bai, X., Hu, H., Jin, M., Yu, Y., Ikeda, M., Johnson, W., Perie, W., Fujisaki, A., 2014. A modeling study of coastal circulation and landfast ice in the nearshore Beaufort and Chukchi seas using CIOM. J. Geophys. Res. Oceans 119 (6), 3285-3312. http://dx.doi.org/10.1002/2013JC009258.

WMO, 1970. WMO sea-ice nomenclature. Terminology, codes and illustrated glossary. Tech. Rep., 259, Geneva Secretariat of the World Meterological Organization.

Young, D.A., Wright, A.P., Roberts, J.L., Warner, R.C., Young, N.W., Greenbaum, J.S., Schroeder, D.M., Holt, J.W., Sugden, D.E., Blankenship, D.D., van Ommen, T.D., Siegert, M.J., 2011. A dynamic early east antarctic ice sheet suggested by icecovered fjord landscapes. Nature 474 (7349), 72-75. http://dx.doi.org/10.1038/ nature10114. 